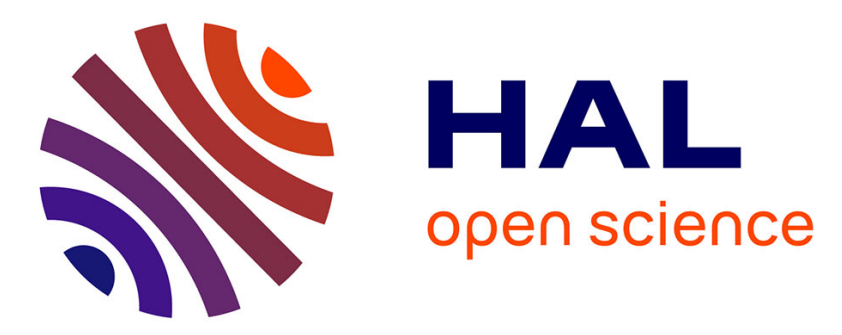

\title{
Experimental Investigation of the Low Temperature Oxidation of the Five Isomers of Hexane
}

Zhandong Wang, Olivier Herbinet, Zhanjun Cheng, Benoit Husson, René Fournet, Fei Qi, Frédérique Battin Leclerc

\section{- To cite this version:}

Zhandong Wang, Olivier Herbinet, Zhanjun Cheng, Benoit Husson, René Fournet, et al.. Experimental Investigation of the Low Temperature Oxidation of the Five Isomers of Hexane. Journal of Physical Chemistry A, 2014, 118 (30), pp.5573-5594. 10.1021/jp503772h . hal-01056660

\section{HAL Id: hal-01056660 https://hal.science/hal-01056660}

Submitted on 20 Aug 2014

HAL is a multi-disciplinary open access archive for the deposit and dissemination of scientific research documents, whether they are published or not. The documents may come from teaching and research institutions in France or abroad, or from public or private research centers.
L'archive ouverte pluridisciplinaire HAL, est destinée au dépôt et à la diffusion de documents scientifiques de niveau recherche, publiés ou non, émanant des établissements d'enseignement et de recherche français ou étrangers, des laboratoires publics ou privés. 


\title{
Experimental Investigation of the Low Temperature Oxidation of the Five Isomers of Hexane
}

\author{
Zhandong WANG ${ }^{1,2}$, Olivier HERBINET ${ }^{1,}{ }^{*}$, Zhanjun Cheng ${ }^{2}$, Benoit HUSSON ${ }^{1}$, René Fournet ${ }^{1}$, Fei \\ $\mathrm{QI}^{2}$, Frédérique BATTIN-LECLERC ${ }^{1}$
}

${ }^{1}$ Laboratoire Réactions et Génie des Procédés, Nancy Université, CNRS UPR 3349, BP 20451, 1 rue Grandville, 54000 Nancy, France

${ }^{2}$ National Synchrotron Radiation Laboratory, University of Science and Technology of China,

Hefei, Anhui 230029, P. R. China.

\begin{abstract}
The low-temperature oxidation of the five hexane isomers ( $n$-hexane, 2-methyl-pentane, 3-methyl-pentane, 2,2-dimethyl-butane, and 2,3-dimethyl-butane) was studied in a jet-stirred reactor (JSR) at atmospheric pressure under stoichiometric conditions between 550 and $1000 \mathrm{~K}$. The evolution of reactant and product mole fraction profiles were recorded as a function of the temperature using two analytical methods: gas chromatography and synchrotron vacuum ultraviolet photoionization mass spectrometry (SVUV-PIMS). Experimental data obtained with both methods were in good agreement for the five fuels. These data were used to compare the reactivity and the nature of the reaction products and their distribution. At low temperature (below $800 \mathrm{~K}$ ), $n$-hexane was the most reactive isomer. The two methyl-pentane isomers have about the same reactivity, which was lower than that of $n$-hexane. 2,2-Dimethyl-butane was less reactive than the two methyl-pentane isomers, and 2,3-dimethyl-butane was the least reactive isomer. These observations are in good agreement with research octane numbers given in the literature. Cyclic ethers with rings including 3, 4, 5, and 6 atoms have been identified and quantified for the five fuels. While the cyclic ether distribution was notably more detailed than in other literature of JSR studies of branched alkane oxidation, some oxiranes were missing among the cyclic ethers expected from methyl-pentanes. Using SVUVPIMS, the formation of $\mathrm{C} 2-\mathrm{C} 3$ monocarboxylic acids, ketohydroperoxides, and species with two carbonyl groups have also been observed, supporting their possible formation from branched reactants. This is in line with what was previously experimentally demonstrated from linear fuels. Possible structures and ways of decomposition of the most probable ketohydroperoxides were discussed. Above $800 \mathrm{~K}$, all five isomers have about the same reactivity, with a larger formation from branched alkanes of some unsaturated species, such as allene and propyne, which are known to be soot precursors.
\end{abstract}

Keywords: oxidation, jet-stirred reactor; synchrotron VUV mass spectrometry; gasoline; hexane

\author{
*Corresponding author information: \\ Olivier HERBINET \\ Laboratoire Réactions et Génie des Procédés, Ecole Nationale Supérieure des Industries Chimiques, BP \\ 20451, 1 rue Grandville, 54000 Nancy, France \\ Tel: +33 (0)3 831753 60, Fax: +33 (0)3 831781 20, E-mail: olivier.herbinet@ensic.univ-lorraine.fr
}




\section{Introduction}

$n$-Alkanes and iso-alkanes are two important families of hydrocarbons which are present in conventional fuels derived from petroleum (1) and Fischer-Tropsch fuels (2). The oxidation of $n$-alkanes (3-16) and iso-alkanes (3-8,17-20) has been the subject of numerous experimental studies. But there are only a few experimental studies with the aim to show the difference of reactivity at low temperature according to the structure of the different isomers of alkanes $(3-5,7,8)$.

Several studies compared the ignition delay times of $n$ - and iso-butanes (3-6). In 2007, Ogura et al. (3) measured ignition delay times of mixtures of $n$-butane and iso-butane ( $1 \%$ of fuel, equivalence ratio of 0.72 with dilution in argon) behind reflected shock waves by monitoring time histories of UV emission and pressure in the temperature range of $1200-1600 \mathrm{~K}$. This experimental study showed that the ignition delay time of iso-butane was longer than that of $n$-butane. In 2010, Healy et al. $(4,5)$ performed rapid compression machine and shock-tube ignition experiments for fuel/air mixtures for $n$ - and iso-butanes at equivalence ratios of $0.3,0.5,1$, and 2 . The wide range of studied experimental conditions included temperatures from 590 to $1567 \mathrm{~K}$ and pressures of approximately 1, 10, 20, 30, and $45 \mathrm{~atm}$. It was also found that iso-butane was less reactive than $n$-butane and that both species exhibit a slight negative temperature coefficient (NTC) behavior. Gersen et al. (6) also measured ignition delay times of $n$ - and iso-butanes in a rapid compression machine in the temperature range of 660-1010 K, at pressures from 14 to 36 bar and at equivalence ratios of 1.0 and 0.5 . They obtained conclusions similar to that of Healy et al. $(4,5)$.

$C_{5}$ and $C_{7}$ alkane isomers $(7,8)$ are the only other species for which ignition delay times were compared in an extensive way. In 1996, Minetti et al. (7) measured ignition delay times of $n$-pentane, iso-pentane, and neopentane in a rapid compression machine over the temperature range of $600-950 \mathrm{~K}$, the pressure range of 6-11 bar, at an equivalence ratio of 1 and in air. This study again showed that the linear isomer was the most reactive species and that neo-pentane, the most branched isomer, was the least reactive, with the reactivity of iso-pentane being in between. In 2005, Silke et al. (8) measured ignition delay times for the nine isomers of heptane ( $n$-heptane, 2-methyl-hexane, 3-methyl-hexane, 2,2-dimethyl-pentane, 2,3-dimethyl-pentane, 2,4-dimethyl-pentane, 3,3-dimethyl-pentane, 3-ethyl-pentane, and 2,2,3-trimethylbutane) using a rapid compression machine. Stoichiometric fuel-air mixtures were studied at compressed gas pressures of 10, 15, and $20 \mathrm{~atm}$ for the $n$-heptane study and at $15 \mathrm{~atm}$ for all other isomers, in the compressed gas temperature range of 640-960 K. NTC behavior was observed for each of the isomers, with the most branched isomer exhibiting a lower reactivity than other isomers. Besides, three branched isomers of octane (2-methylheptane (19), 3-methyl-heptane (20), and 2,5-dimethyl-hexane (21)) have been studied in a jet-stirred reactor operated at $10 \mathrm{~atm}$ under the same conditions (initial mole fraction of 0.001 ). The results indicate about the same reactivity for the three compounds.

All these studies showed that linear alkanes are more reactive than branched species and that the position of methyl groups can also have an impact on the reactivity and the product selectivity. This observation can be related to the evolution of octane numbers for the antiknock rating of gasoline fuels. As an example, the research octane number (RON) of $n$-butane is 94 , whereas the RON of iso-butane is 102 , meaning that iso-butane ignites with more difficulty than $n$-butane under the engine test conditions. The ability of $n$-butane to ignite easily is related to the higher reactivity of linear alkanes at low temperature. The linearity of the molecule favors the formation of branching agents providing the multiplication of radicals and the heat release $(22,23)$. 
Eskola et al. studied the reactions of $n$ - and iso-butyl radicals with oxygen using chlorine laser-photolysis to initiate the low-temperature oxidation of $n$-butane (24) or iso-butane (25) in a flow tube using molecular beam photoionization mass spectrometry. They observed the formation of ketohydroperoxides from the linear reactant but not from the branched one.

The goal of this paper is to present new experimental results from the study of the low-temperature oxidation of the five isomers of hexane (see structures in Figure 1) with an analysis of a maximum of reaction products, including ketohydroperoxides which have not yet been detected from branched reactants. In accordance with the research octane numbers (26) given in Table $1, n$-hexane is the most reactive isomer, 2 - and 3-methyl-pentanes have about the same reactivity, 2,2-dimethyl-butane is much less reactive than the two methyl-pentane isomers, and 2,3-dimethyl-butane is the least reactive isomer. In spark ignition engines, due to gas compression, fuels with low octane numbers (e.g., $n$-heptane) start to react and self-ignite before the spark plug ignition occurs. This is the cause of a sharp metallic sound called knocking. Research octane numbers, which characterize the tendency of fuels to resist autoignition, are measured in a cooperative fuel research engine. The fuel reactivity during the compression is directly related to low-temperature oxidation chemistry, which is responsible for the cool flame occurring prior to the self-ignition (26).

Experiments carried out in this work were performed using a jet-stirred reactor. This type of reactor is well adapted to the kinetic studies of fuel low-temperature oxidation chemistry, although the conditions are different from those observed in an engine (the present reactor is an isothermal continuous flow reactor working at atmospheric pressure, whereas an engine is a closed vessel with variable volume working at significantly higher pressures, up to 30 bar). The advantage of using this type of reactor is the possibility of comparing the reactivity of the different hexane isomers but also of highlighting the differences in the nature and the concentration profiles of the reaction products under well-defined conditions. These data are useful for a better understanding of the low-temperature oxidation chemistry of alkanes and for further validations of detailed kinetic models of the oxidation of hexane isomers. Experiments were performed using two complementary analytical methods: gas chromatography analyses in Nancy (France) and synchrotron vacuum ultraviolet photoionization mass spectrometry (SVUV-PIMS) analyses in Hefei (China). The same reactor and analytical methods have been recently used to investigate the low-temperature oxidation of the three isomers of hexane (27).

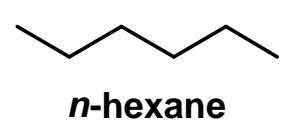

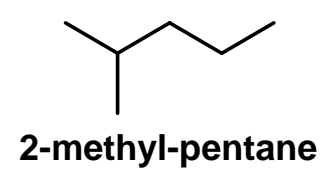

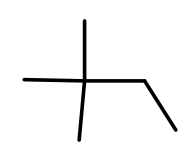

2,2-dimethyl-butane

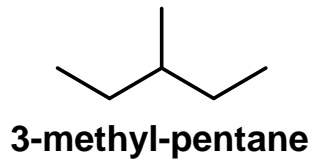<smiles>CC(C)C(C)C</smiles>

2,3-dimethyl-butane

Figure 1. Structures of the five isomers of hexane. 
Table 1. Research Octane Numbers (RON) of the Five Hexane Isomers (26).

\begin{tabular}{ll}
\hline Species & RON \\
\hline$n$-hexane & 24.8 \\
2-methyl-pentane & 73.4 \\
3-methyl-pentane & 74.5 \\
2,2-dimethyl-butane & 91.8 \\
2,3-dimethyl-butane & 103.5 \\
\hline
\end{tabular}

\section{Experimental Method}

The oxidation of the isomers of hexane was studied using a jet-stirred reactor (JSR), a type of reactor described in detail in ref 28 . This type of reactor has often been used by our research team in Nancy for gas phase kinetic studies of the oxidation of hydrocarbon and oxygenated molecule under isothermal conditions (29-32). Experiments were performed at a constant pressure of 1.06 bar, at a residence time of $2 \pm 0.1 \mathrm{~s}$, at temperatures ranging from 550 to $1000 \mathrm{~K}$, under stoichiometric conditions, and the fuel was diluted in an inert gas (inlet mole fraction of 0.02 for the five isomers and 0.04 for 2,2- and 2,3-dimethyl-butanes). Inlet mole fraction values were chosen for the least reactive compound to show enough reactivity at low temperature. However, the chosen values are relatively high, and the range of investigated temperatures had to be reduced for the most reactive species to avoid a too large exothermicity in the reactor (as an example, the oxidation of $n$-hexane was studied in the temperature range of 550-850 K). The inert gas was helium in Nancy and Argon in Hefei. Argon was required in Hefei because its signal at a photoionization energy of $16.6 \mathrm{eV}$ is used for the normalization of the signals of other peaks.

The reactor, made of fused silica, consists of a quartz sphere (volume $\approx 90 \mathrm{~cm}^{3}$ ) into which the diluted reactant enters through an injection cross located at its center. A lateral sampling cone was inserted in the reactor used in Hefei for the connection with the mass spectrometer. The reactor is operated at constant temperature and pressure. It is preceded by an annular preheating zone in which the temperature of the gases is increased up to the reaction temperature before entering into the reactor. Gas mixture residence time inside the annular preheater is very short compared to the residence time inside the reactor (a few percent). In Nancy, both the spherical reactor and the annular preheating zone are heated by Thermocoax heating resistances rolled up around their walls. In Hefei, an oven having the same shape as the reactor with its lateral cone was used to provide the heating of the reactor part. The uncertainty in the reaction temperature measurement was estimated to $\pm 5 \%$ with both devices (resistances in Nancy and oven in Hefei). Gas flow rates for the feed of the reactor were controlled by mass flow controllers provided by Bronkhorst for the experiments in Nancy and by mass flow controllers provided by MKS and Bronkhorst in Hefei. In accordance with manufacturers, errors in mass flow measurements were $\pm 0.5 \%$. Liquid flow rates were controlled by Coriolis flow controllers provided by Bronkhorst. The uncertainty in fuel flow rates was $\pm 1 \%$.

Fuels used in China were provided by Aladdin Reagent ( $n$-hexane assay $\geq 99 \%$ and 2,3-dimethyl-butane assay $\geq 98 \%$ ) and by Alfa Aesar (methyl-pentane isomers assay $\geq 99 \%$ and 2,2-dimethyl-butane assay $\geq 98.5 \%$ ). Fuels used in France were provided by Sigma-Aldrich (assay $\geq 97 \%$ for $n$-hexane, $\geq 98 \%$ for 2,3-dimethyl-butane, and $\geq 99 \%$ for other isomers).

\subsection{Gas Chromatography Analyses (Nancy)}

Analyses in Nancy were performed using online gas chromatography. The online analysis of products which are liquid under standard conditions was performed by a heated transfer line between the reactor outlet and the chromatograph sampling gate which was also heated. The temperature of the transfer line was set at 
$423 \mathrm{~K}$. This temperature was high enough to keep all the reaction products in the gas phase. Three gas chromatographs were used for the quantification of the different species.

The first gas chromatograph, equipped with a Carbosphere packed column, a thermal conductivity detector (TCD), and a flame ionization detector (FID), was used for the quantification of $\mathrm{O}_{2}, \mathrm{CO}, \mathrm{CO}_{2}$, methane, ethylene, acetylene, and ethane. The second one was fitted with a PlotQ capillary column and a FID and was used for the quantification of molecules from methane to reaction products with up to 5 carbon atoms and 1 to 2 oxygen atoms maximum. The third one was fitted with a HP-1 capillary column and a FID. It was used for the quantification of heavier species with more than five heavy atoms.

Note that $\mathrm{C}_{2}-\mathrm{C}_{4}$ carboxylic acids were observed by $\mathrm{GC}$ analyses but with much larger mole fractions than those measured by SVUV-PIMS (about a factor of 10). In accordance with previous studies (32), larger mole fractions of these species measured by GC are likely due to the decomposition of unstable species (e.g., ketohydroperoxides) in the heated transfer line between the outlet of the reactor and the GC. These results will then not be presented in this paper.

The identification of reaction products, which were not calibrated beforehand, was performed using a gas chromatograph equipped with a PlotQ or HP-1 capillary column and a mass spectrometer. The mass spectra of most reaction products were included in the NIST 08 mass spectral library. When mass spectra were not available (e.g., for species like cyclic ethers formed from the low-temperature oxidation of branched alkanes), the deciphering of the experimental mass spectra was carried out. The mass spectra of all the cyclic ethers which are not available in the NIST 08 mass spectral library are given in the Supporting Information.

The calibration was performed by injecting known amounts of the pure substances when available, otherwise the method of the effective carbon number was used (species having the same number of carbon atoms and the same functional groups were assumed to have the same response in the FID). The detection threshold was about $100 \mathrm{ppb}$ for the heaviest species (FID) and about $100 \mathrm{ppm}$ for carbon monoxide, carbon dioxide, and oxygen (TCD). On the basis of the experimental repeatability, uncertainty estimates on obtained mole fractions were about $\pm 5 \%$ (measurement reading) for species which were calibrated using gaseous standards (oxygen, fuels, $\mathrm{CO}, \mathrm{CO}_{2}$, and $\mathrm{C}_{1}-\mathrm{C}_{4}$ hydrocarbons) and $\pm 10 \%$ for those calibrated using the effective carbon number method (33).

\subsection{SVUV-PIMS Analyses (Hefei)}

In Hefei, species from the reactor were analyzed by a reflectron time-of-flight mass spectrometer (RTOF MS) with photoionization by synchrotron radiation. This apparatus was already described in detail in ref 34 . The reactor was coupled to the low pressure photoionization chamber through a lateral fused silica cone-like nozzle, which was inserted in the spherical part. The tip of the cone was pierced by a $50 \mu \mathrm{m}$ orifice. A nickel skimmer with a $1.25 \mathrm{~mm}$ diameter aperture was located $15 \mathrm{~mm}$ downstream from the sampling nozzle. The sampled gases formed a molecular beam, which passed horizontally through the $10 \mathrm{~mm}$ gap between the repeller and extractor plates of RTOF MS. The molecular beam intersected perpendicularly with synchrotron vacuum ultraviolet light. The ion signal was then detected with the RTOF MS, which was installed in the photoionization chamber vertically. Details about the tunable synchrotron light are available in ref 35 . The evolution of ion signals was recorded as a temperature function (from 500 to $700 \mathrm{~K}$ ) over the mass range of 2-172 Da and at several photon energies $(9.5,10,10.5,11,13$, and $16.6 \mathrm{eV})$. Scans in energy were also 
performed at the temperature of $625 \mathrm{~K}$ for the identification of species, according to their ionization energies. The ion signal of argon measured at $16.6 \mathrm{eV}$ was used to normalize ion signals obtained for other masses.

The quantification of reactants (fuels and oxygen) was carried out by measuring the signal under unreactive conditions. Reaction products were quantified from equation 1 using another species as reference (a reactant or a product, whose mole fraction and cross section are already known).

$x_{i}(T)=x_{r e f}(T) \times \frac{S_{i}(T, E)}{S_{r e f}(T, E)} \times \frac{\sigma_{r e f}(E)}{\sigma_{i}(E)} \times \frac{D_{r e f}}{D_{i}}$

where $x_{i}(T)$ and $S_{i}(T, E)$ are the mole fraction and the signal of species $i$ at the temperature $T$ and at the photon energy $E$, respectively.

$\sigma_{i}(E)$ is the photo-ionization cross-section of species $i$ at the photon energy $E$.

$D_{i}$ is the mass discrimination factor of species $\mathrm{i}$.

Carbon monoxide, Carbon dioxide, water, and methane mole fractions were calculated using equation 1, and the signal of $\mathrm{m} / \mathrm{z} 40$ (argon) at $16.6 \mathrm{eV}$ as reference. Cross sections at $16.6 \mathrm{eV}$ used for the calculation were 32.1 (36), 19.42 (37), 34.88 (38), 15.1 (39), and $44.38 \mathrm{Mb}$ (40) for argon, carbon monoxide, carbon dioxide, water, and methane, respectively.

Other products were quantified using the related hydrocarbon fuels as the reference. Cross sections were only available in the literature for $n$-hexane (41). Cross sections of the four other hexane isomers were measured, as well as that of $n$-hexane, in the present study. The data are presented in Figure 2 as well as that of $n$-hexane measured in ref 41 . Formaldehyde, methanol, acetic acid, propanoic acid, and ethylene were quantified using the signals obtained at a photon energy of $11 \mathrm{eV}$; acetaldehyde, propene, 1-butene, and iso-butene were quantified using the signals at $10.5 \mathrm{eV}$. Cross sections at $11 \mathrm{eV}$ were 9.02 (42), 3.63 (43), 6.82 (32), 11.96 (32), and $7.79 \mathrm{Mb}$ (43) for formaldehyde, methanol, acetic acid, propanoic acid, and ethylene, respectively. Cross sections at $10.5 \mathrm{eV}$ were 4.4 (44), 11.09 (45), 9.91 (45), and $10.08 \mathrm{Mb}$ (46) for acetaldehyde, propene, 1-butene, and iso-butene, respectively.

Uncertainties were estimated to $\pm 10 \%$ for species, which were directly calibrated using standards when available (hexane fuels, oxygen, and argon) and to $\pm 25 \%$ for species quantified by the mean of equation 1 with known photoionization cross sections.

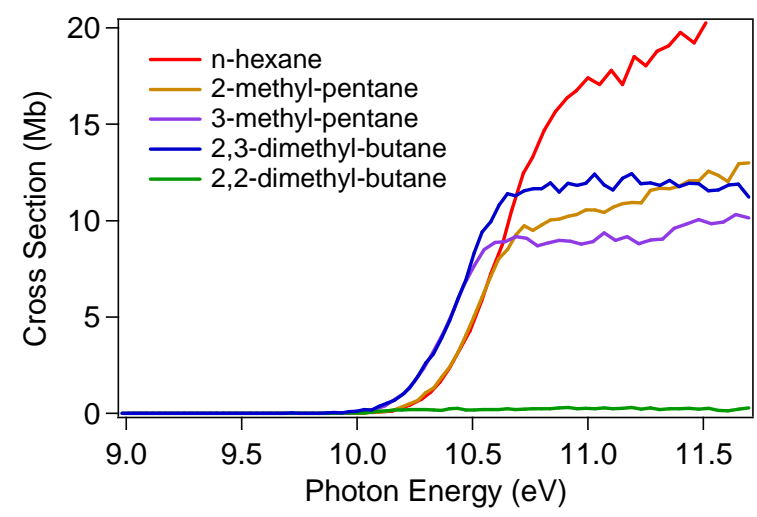

Figure 2. Evolution of the cross sections of the five hexane isomers as a function of the photon energy (data were obtained in the present work except for $n$-hexane (41)). 


\section{Experimental Results and Discussion}

Experiments performed in Hefei were repeated in Nancy using the same conditions. In the first part of this section, both sets of experimental results obtained for 3-methyl-pentane are compared in order to show the agreement between both analytical methods. The comparison for other hexane isomers is given as Supporting Information. In the second part, the reactivity and the concentration profiles of the common reaction products are compared for the five isomers of hexane, using the data obtained by gas chromatography or by SVUV-PIMS for species that could not be analyzed using gas chromatography. In the third part, the structures and the concentration profiles of cyclic ethers and large alkenes are discussed. Finally, the fourth part presents the signals obtained for ketohydroperoxides and species, including two carbonyl groups (named from here diones).

\subsection{Comparison of Both Sets of Experimental Results Obtained for 3-Methyl-Pentane}

Experimental mole fractions obtained with both analytical methods have been compared when available for the different fuels. In the text, only the comparison for 3-methyl-pentane is displayed. The comparison for other fuels is given as Supporting Information (except for 2,3-dimethyl-butane, which was not reactive under the conditions used in Hefei). Figures 3 to 5 show that the agreement between both sets of data for 3-methylpentane is overall satisfactory for both the reactants (3-methyl-pentane and oxygen in Figure 3 ) and the reaction products (oxygenated species in Figure 4 and hydrocarbons in Figure 5). The agreement is also satisfactory for other fuels. Data are displayed in Figures S1 to S9 of the Supplementary Material.
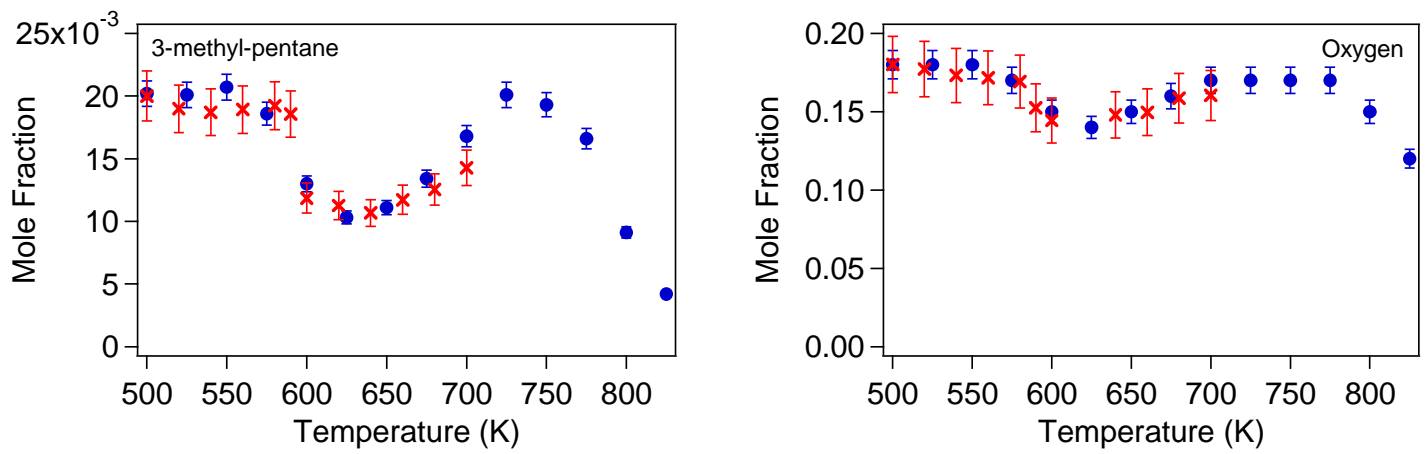

Figure 3. Comparison of mole fraction profiles obtained using gas chromatography $(\bullet)$ and SVUV-PIMS $(x)$ for 3-methyl-pentane and oxygen (fuel inlet mole fraction of 0.02 ). The signals recorded at $11 \mathrm{eV}$ for $\mathrm{m} / \mathrm{z} 86$ and at $16.6 \mathrm{eV}$ for $\mathrm{m} / \mathrm{z} 32$ were used for the quantification of 3-methyl-pentane and oxygen, respectively.

However, it should be noted that an important deviation can be observed between both used analytical methods for propene. This is the case for 3-methyl-pentane in particular. This is due to the formation of ketene, which was simultaneously detected with propene by RTOF MS given that both species have close molecular weights ( $m / z 42.0797$ for propene and $m / z 42.0367$ for ketene) (34). The separation of these two species was not available by the used RTOF MS. Note that ketene was not detected by GC (this may be due to adsorption or decomposition phenomena in the transfer line between the reactor and the GC and also because of the low concentrations of this species). As can be seen from Figure 6 , the visible threshold at around $9.6 \mathrm{eV}$ measured in the SVUV-PIMS experiment well corresponds to the ionization energy of ketene (9.617 eV (47)). Note also that for light species, such as methane or ethylene, the production of fragments from heavier species may perturb the SVUV-PIMS measurements. 

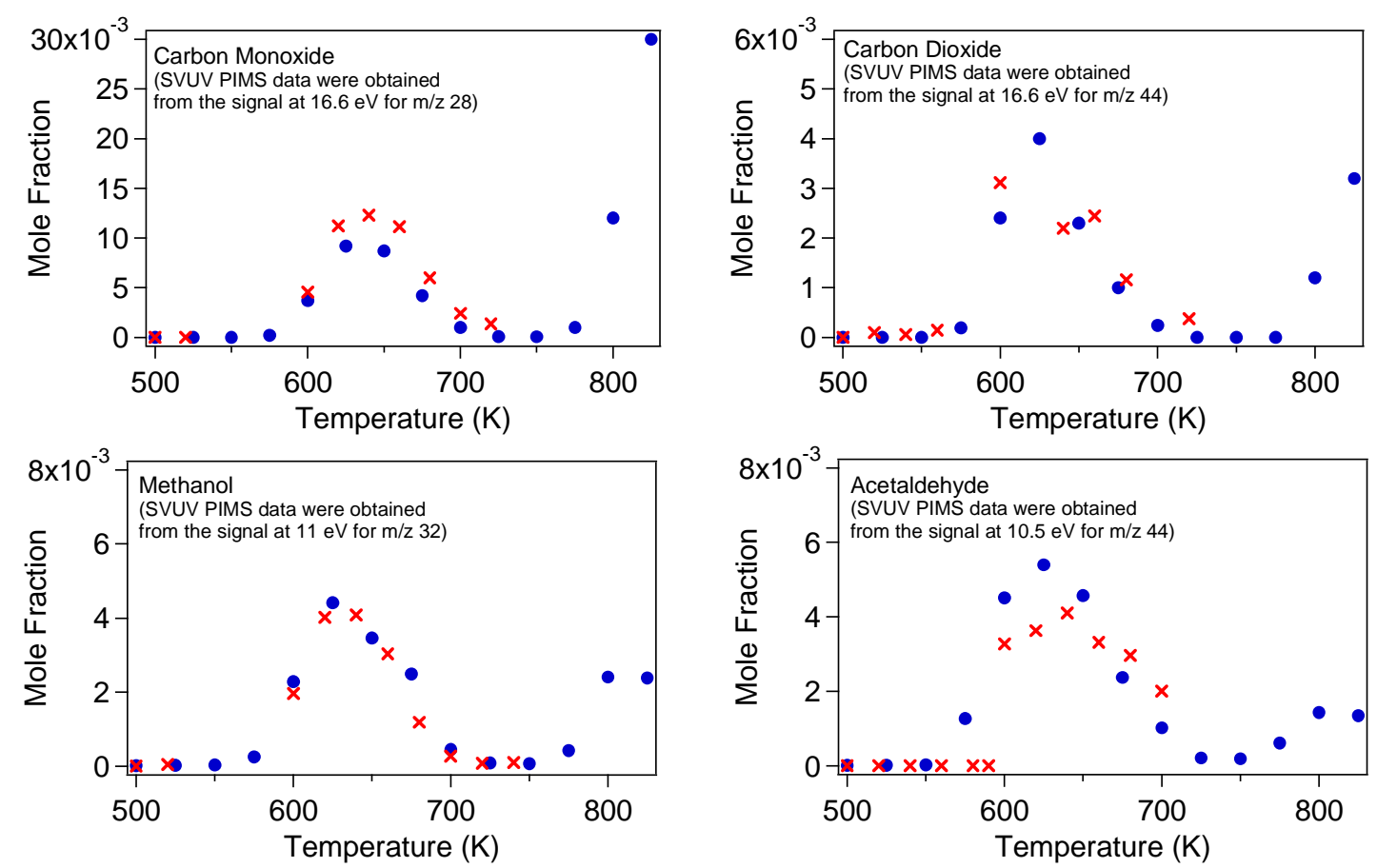

Figure 4. Comparison of mole fraction profiles obtained using gas chromatography $(\bullet)$ and SVUV-PIMS $(x)$ for oxygenated reaction products (3-methyl-pentane inlet mole fraction of 0.02 ).
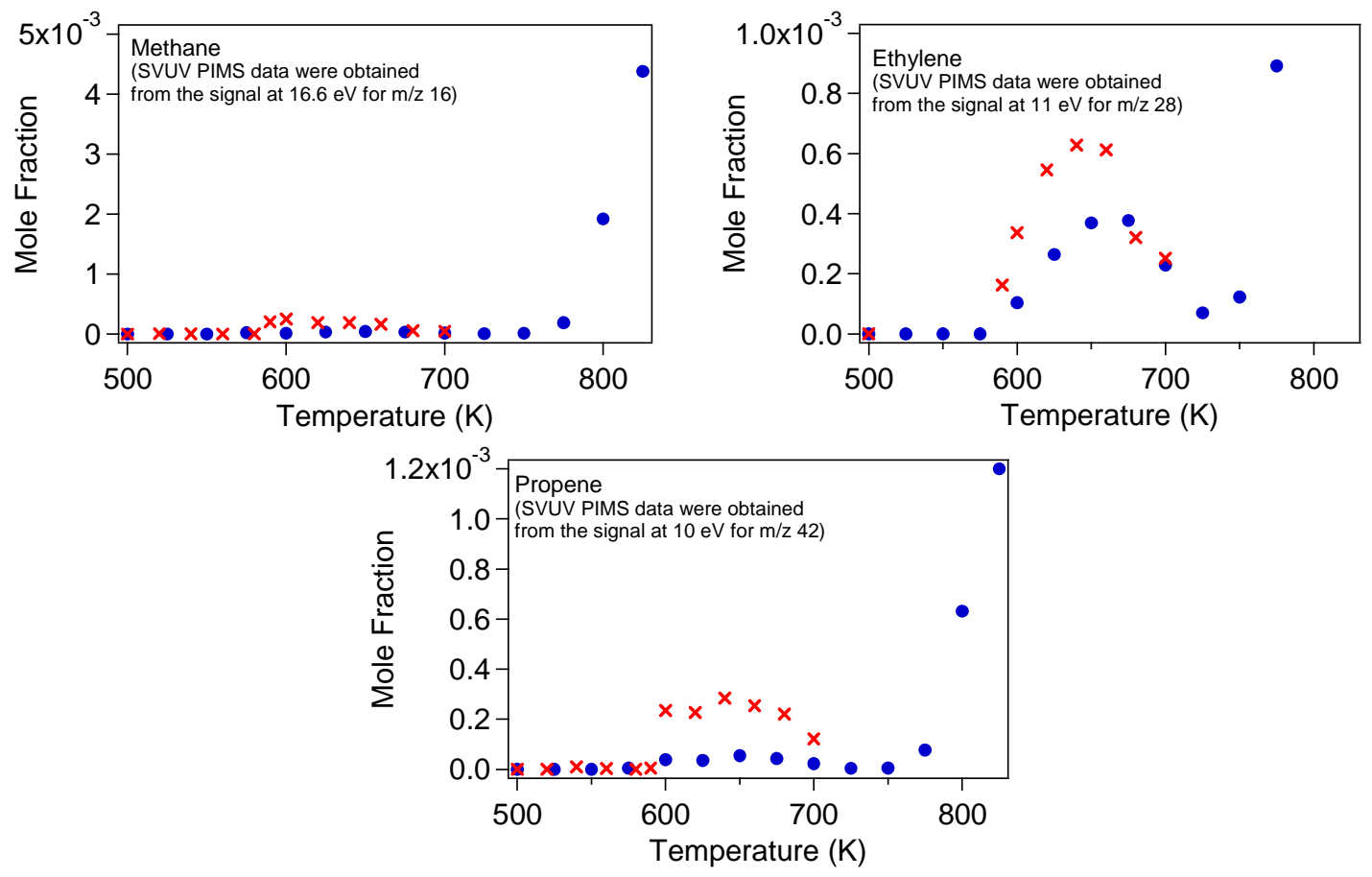

Figure 5. Comparison of mole fraction profiles obtained using gas chromatography $(\bullet)$ and SVUV-PIMS $(x)$ for small hydrocarbon reaction products (3-methyl-pentane inlet mole fraction of 0.02). 

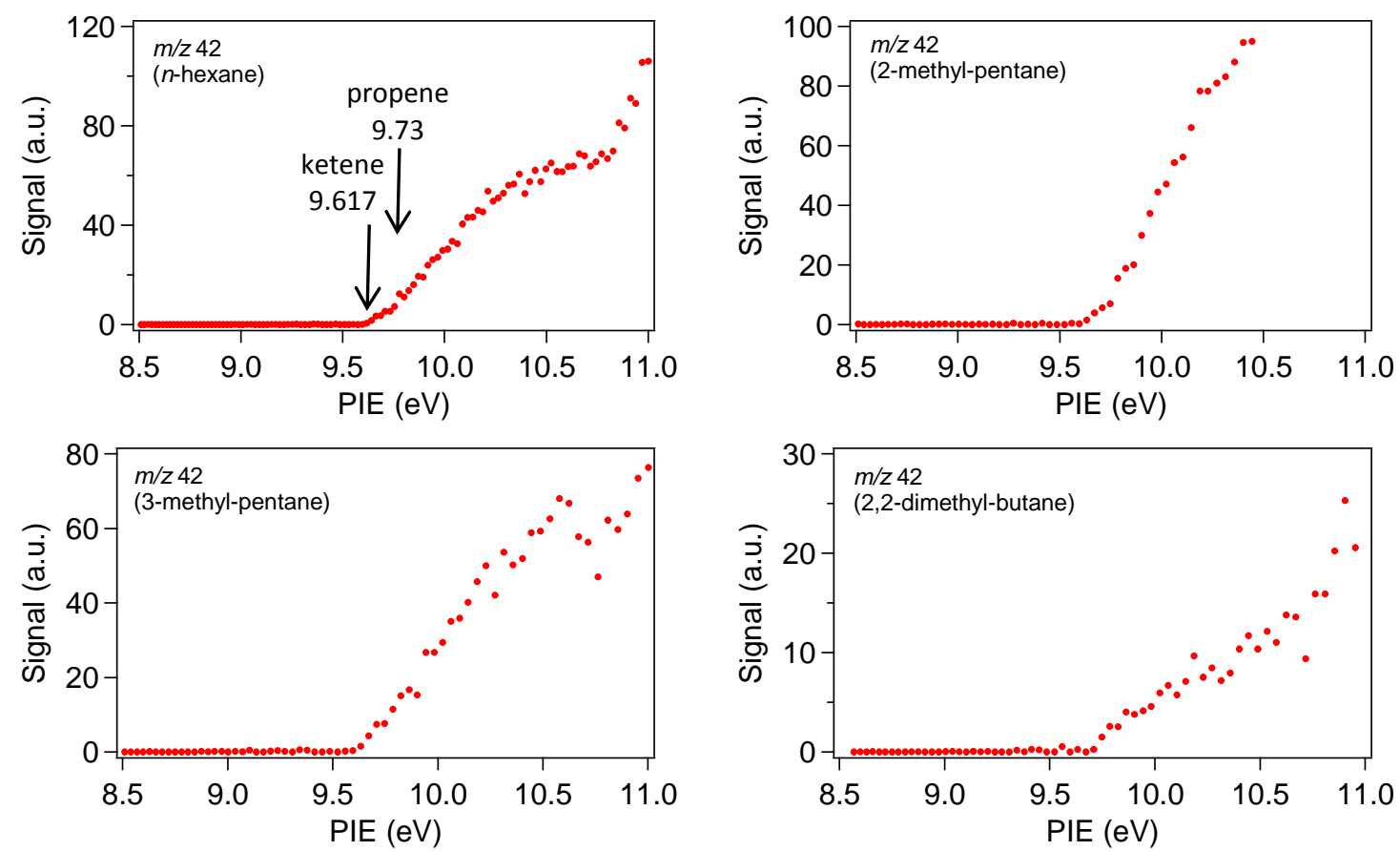

Figure 6. Photoionization efficiency spectra of $\mathrm{m} / \mathrm{z} 42$ obtained during the oxidation of hexane isomers. Temperatures in the reactor were $653,620,620$, and $623 \mathrm{~K}$ for $n$-hexane, 2- and 3-methyl-pentane isomers, and 2,2-dimethyl-butane, respectively.

\subsection{Comparison of the Reactivity of the Five Isomers of Hexane and of the Mole Fractions of Common Reaction Products}

Figure 7 displays the comparison of the experimental fuel mole fraction profiles that were obtained by GC for the five hexane isomers. It can be seen that $n$-hexane is the most reactive isomer with a conversion of about $75 \%$ at $650 \mathrm{~K}$ for an initial mole fraction of 0.02 (Figure 7a) and that it is still reactive in the NTC region. The two methyl-pentane isomers have about the same reactivity (conversion of about $50 \%$ at a temperature of $625 \mathrm{~K}$ ), which is lower than that of $n$-hexane. The position of the methyl groups does not seem to have an impact on the reactivity of the two methyl-pentane isomers. This phenomenon is in agreement with the observation by Karsenty et al. for 2- and 3-methyl-heptanes (20). On the contrary, 2,2- and 2,3-dimethyl-butanes do not have the same reactivity. For an initial mole fraction of 0.02, 2,3-dimethyl-butane has no reactivity at low temperature, whereas 2,2-dimethyl-butane presents a conversion of about $25 \%$ at $625 \mathrm{~K}$ (Figure 7a). An initial mole fraction of 0.04 is needed for a $20 \%$ maximum conversion of 2,3-dimethyl-butane (Figure 7b), while the maximum conversion of 2,2-dimethyl-butane is then close to $50 \%$. Note that these experimental observations are in good agreement with what was expected from the analysis of the research octane numbers given in Table 1. Note that the oxidation of the three most reactive isomers was performed over a limited range of temperature (up to $850 \mathrm{~K}$ ) to avoid autoignition phenomena due to the high fuel inlet mole fractions used in this study. 


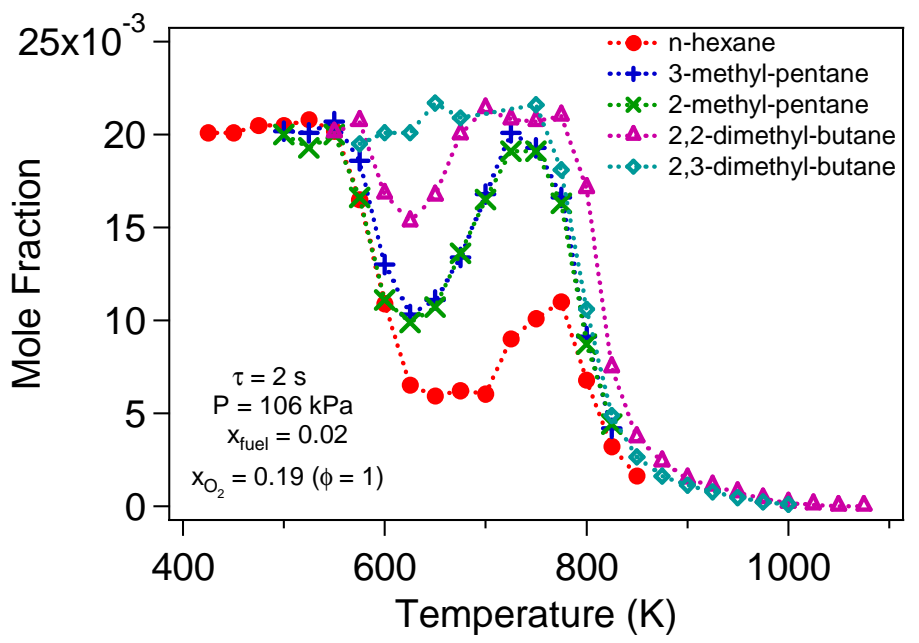

(a)

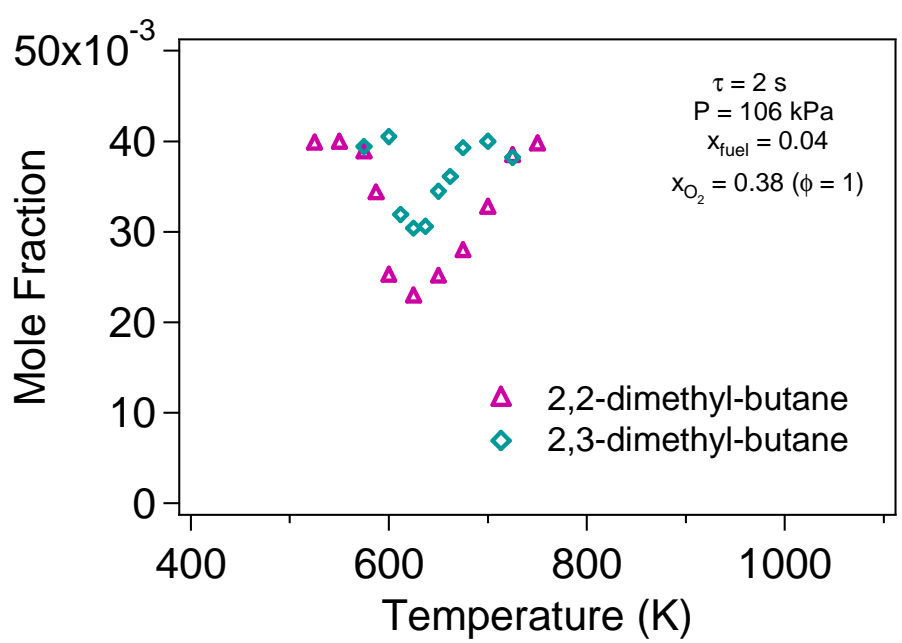

(b)

Figure 7. Comparison of the reactivity of the five hexane isomers (fuel inlet mole fraction of 0.02 in (a) and 0.04 in (b)). Mole fractions were obtained using gas chromatography.

Figures $8,9,10,11$, and 12 display the comparison of the mole fraction profiles of $C_{1}-C_{5}$ hydrocarbons and $\mathrm{C}_{1}-\mathrm{C}_{6}$ oxygenated reaction products obtained in the oxidation of the five hexane isomers using $\mathrm{GC}$ for the analysis. As hexane isomers have different reactivities, selectivities have been calculated at $650 \mathrm{~K}$ in order to do comparisons. The selectivity of a species is obtained by dividing its mole fraction by the sum of mole fractions of all reaction products. Selectivity graphs are displayed in Figure 13 for olefins and carbonyl species. As far as olefins are concerned, it can be seen that the distribution clearly depends on the structure of the fuel. As an example, the experimental propene mole fractions obtained with $n$-hexane and 2-methyl-pentane are larger than those obtained with 3-methyl-pentane and 2,2-dimethyl-butane. These differences can be simply explained by the structure of the fuels (Figure 1): propene cannot be directly formed by $\beta$-scission of fuel radicals obtained from 2,2-dimethyl-butane and 3-methyl-pentane. Also the selectivity of iso-butene is very large in the case of 2,2-dimethyl-butane due to the presence of the tert-butyl structure in the reactant. Note that selectivities of 2-methyl-1-butene and 2-methyl-2-butene are also important in the case of 2,2-dimethyl-butane. 3-Methyl-pentane rather leads to 1- and 2-butenes and 2-methyl-1-butene due to the methyl group located in the middle of the chains. The selectivities of propene and iso-butene are large in the case of 2-methyl-pentane due to the presence of the iso-butyl structure. 

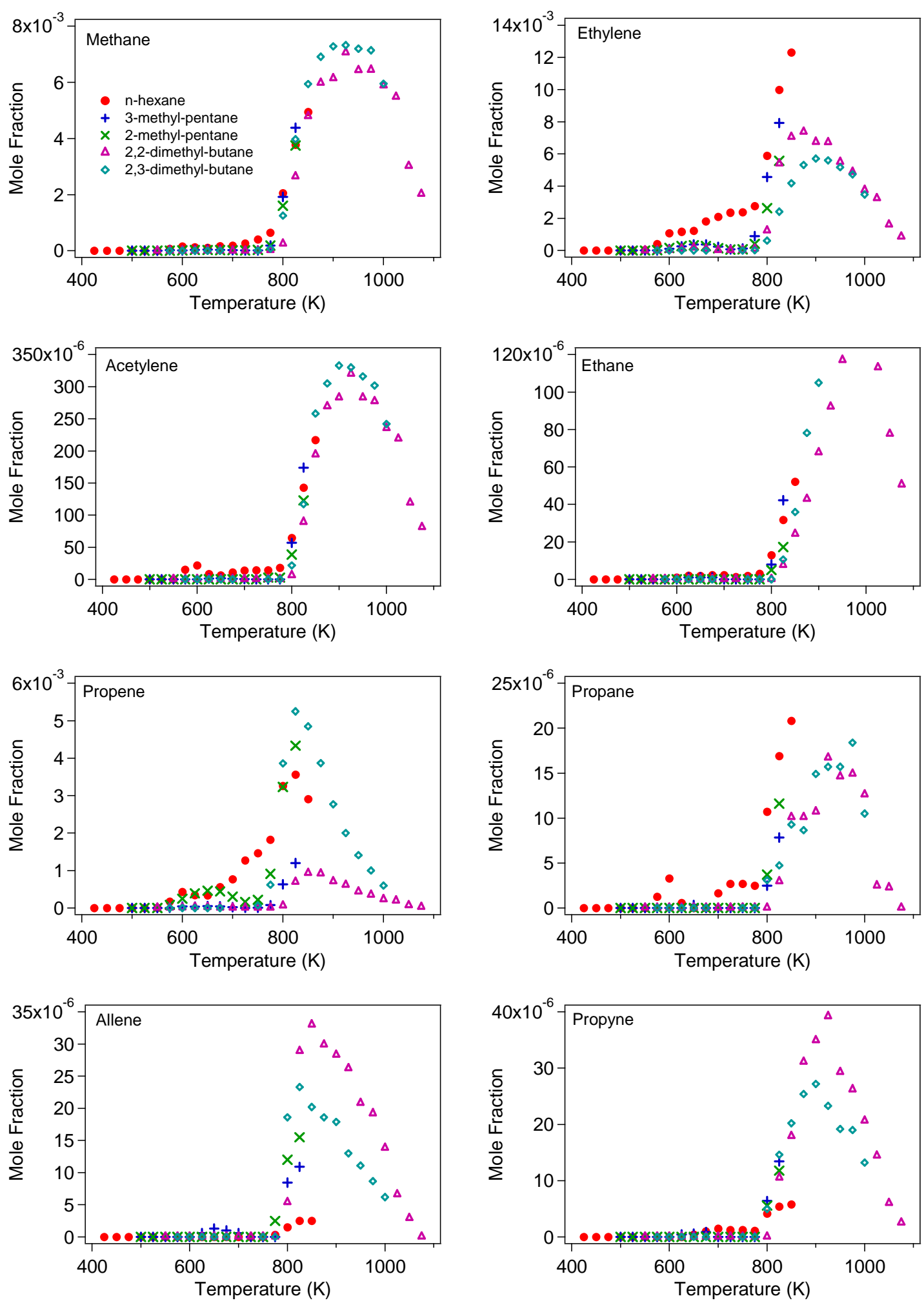

Figure 8. Comparison of mole fraction profiles of the $C_{1}-C_{3}$ hydrocarbons that were observed in the oxidation of the five isomers of hexane (fuel inlet mole fraction of 0.02 ). Mole fractions were obtained using gas chromatography. 

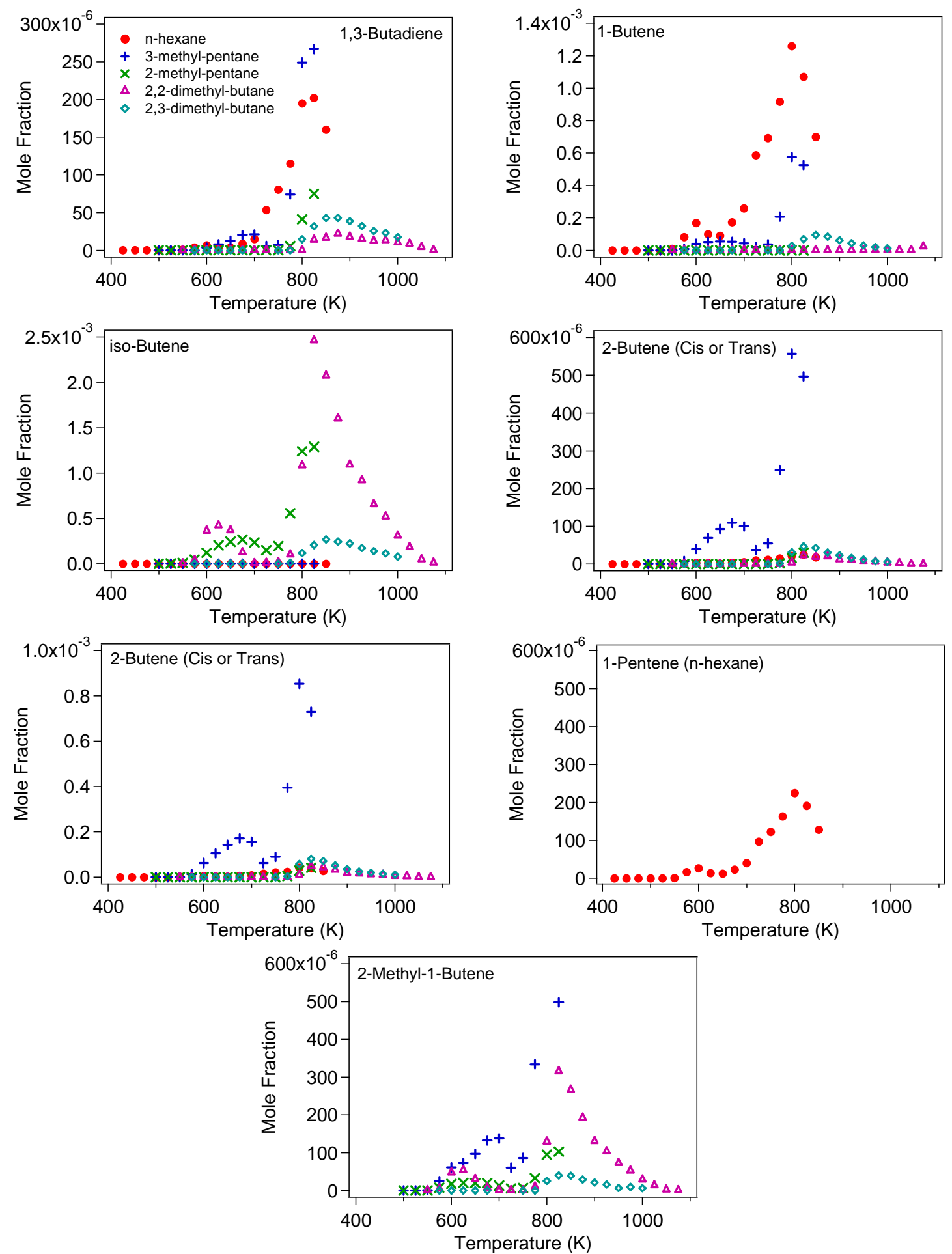

Figure 9. Comparison of mole fraction profiles of the $C_{4}-C_{5}$ hydrocarbons that were observed in the oxidation of the five isomers of hexane (fuel inlet mole fraction of 0.02 ). Mole fractions were obtained using gas chromatography. Note that two isomers were detected for 2-butene, but we were unable to distinguish the cis and the trans configurations. Note also that the formation of 1-pentene was only observed in the oxidation of $n$-hexane, whereas the formation of 2-methyl-1-butene was observed only for the branched hexane isomers. 

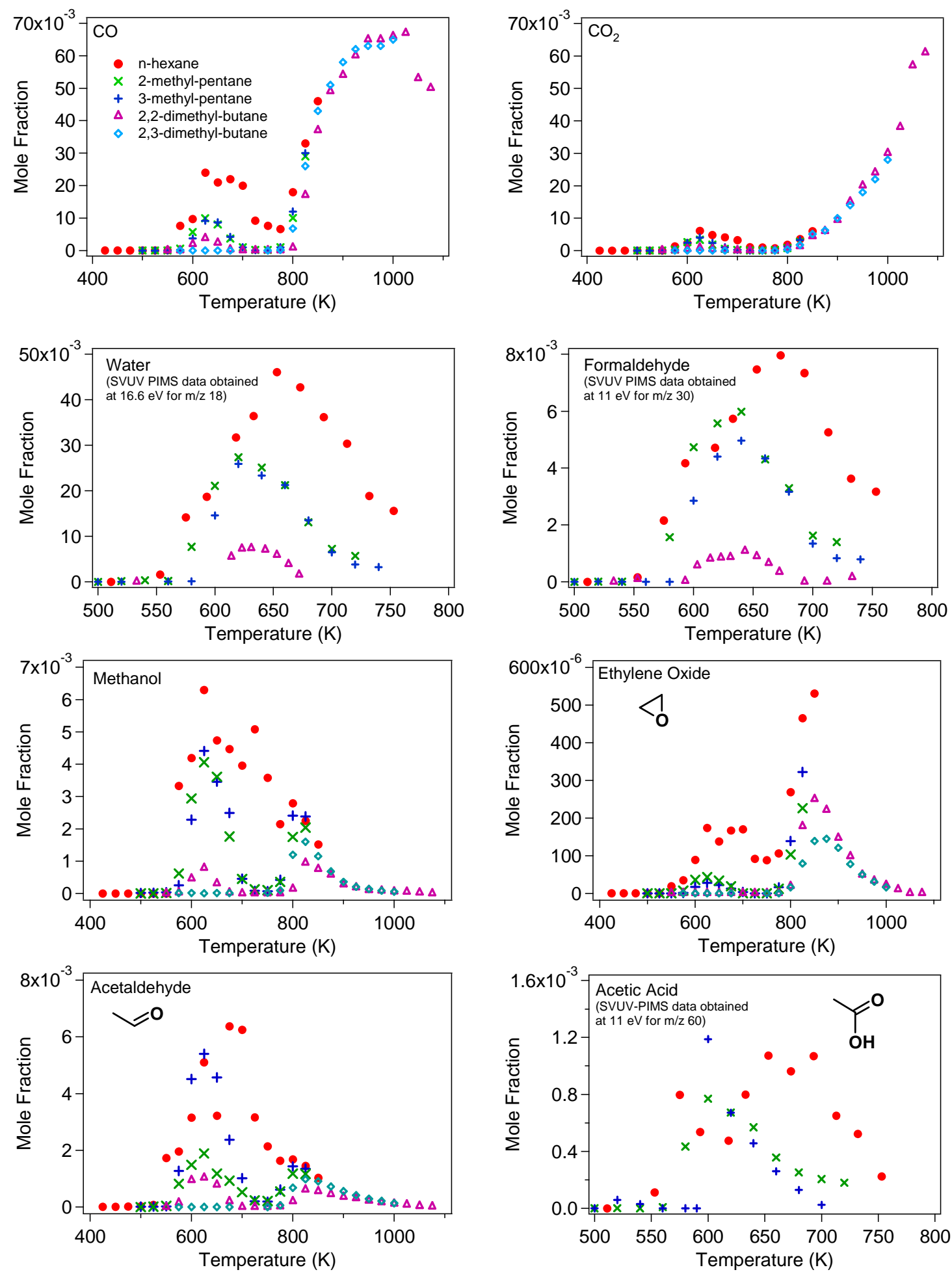

Figure 10. Comparison of mole fraction profiles of the $C_{1}-C_{2}$ oxygenated reaction products that were observed in the oxidation of the five isomers of hexane (fuel inlet mole fraction of 0.02). Mole fractions were obtained using gas chromatography except for water, formaldehyde, and acetic acid. 

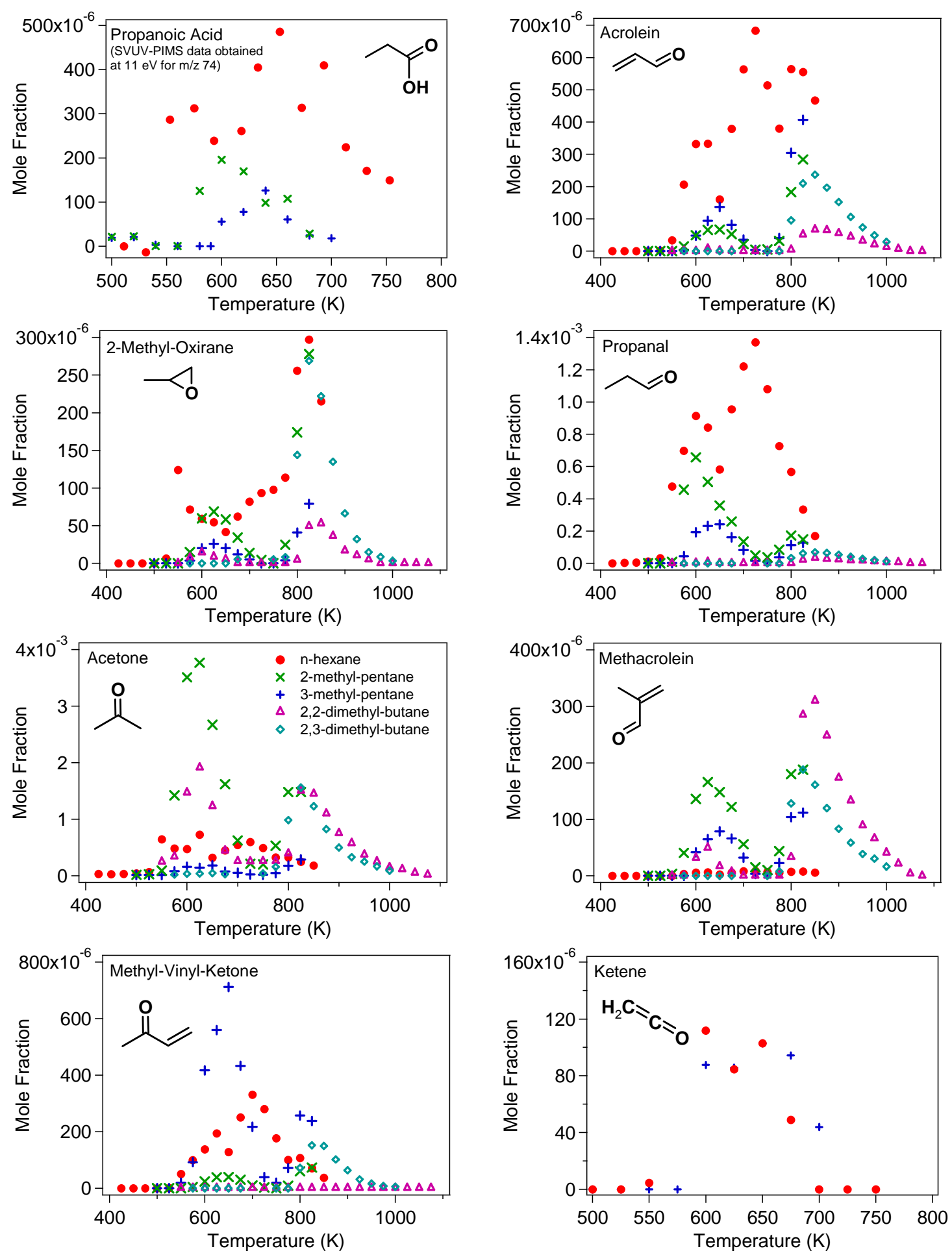

Figure 11. Comparison of mole fraction profiles of ketene and the $C_{3}-C_{4}$ oxygenated reaction products that were observed in the oxidation of the five isomers of hexane (fuel inlet mole fraction of 0.02). Mole fractions were obtained using gas chromatography. 

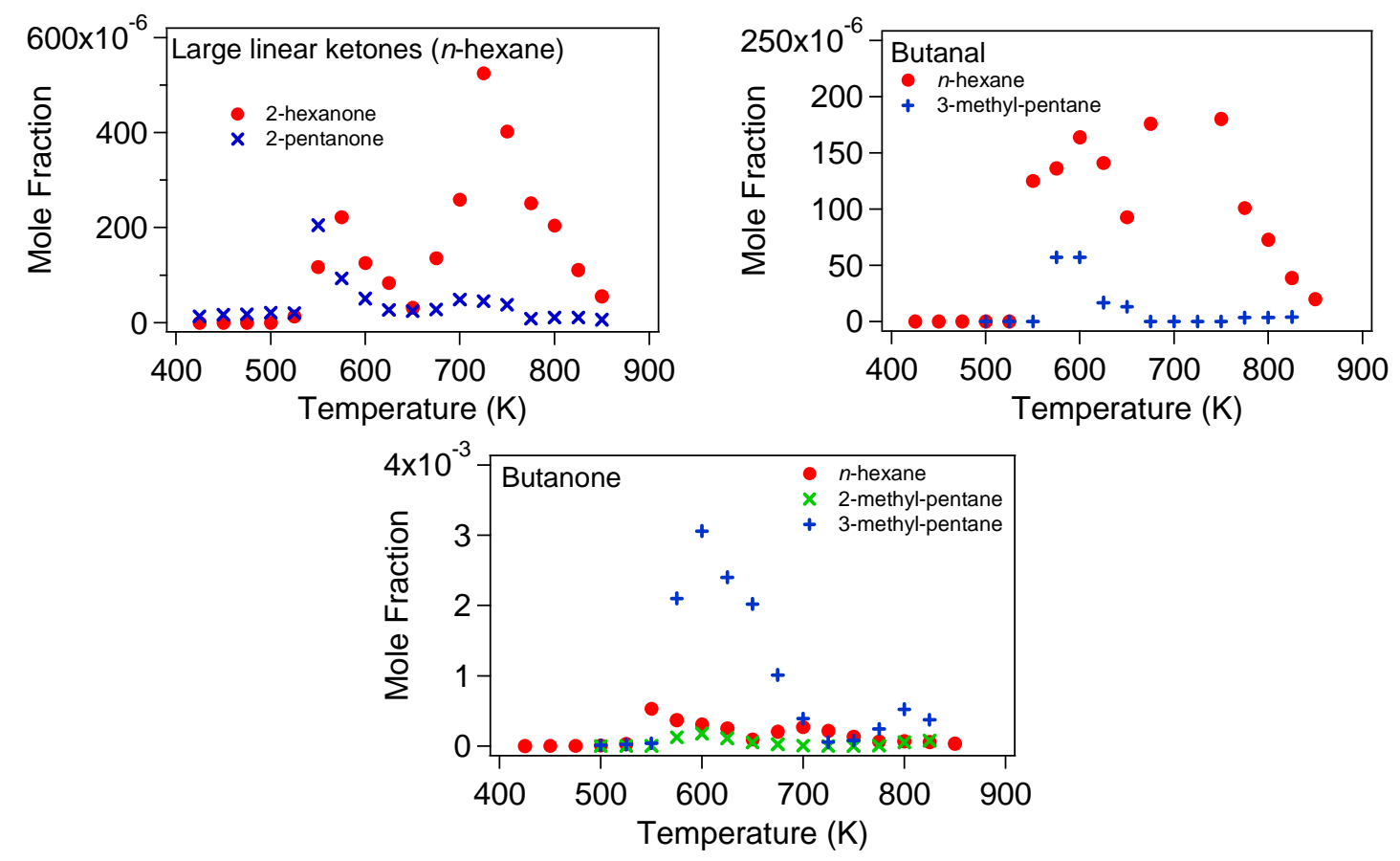

Figure 12. Mole fractions of ketones and aldehydes obtained in the oxidation of hexane isomers (fuel inlet mole fraction of 0.02). Mole fractions were obtained using gas chromatography.

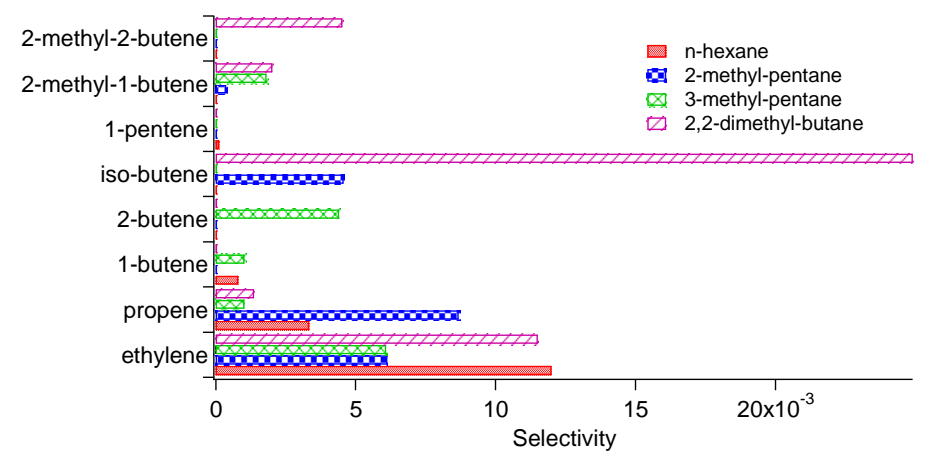

a)

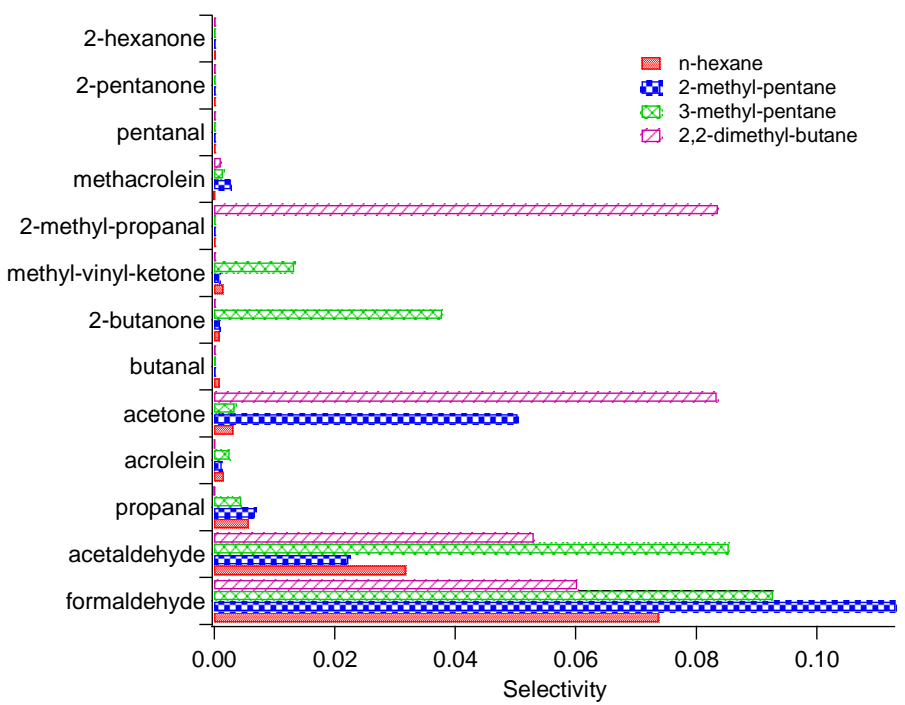

b)

Figure 13. Comparison of the selectivities of olefins and carbonyl species at $650 \mathrm{~K}$. 
As far as carbonyl compounds are concerned, the formation of acetone and 2-methyl-propanal is enhanced in the case of 2,2-dimethyl-butane. Methacrolein is likely a product coming from the oxidation of iso-butene through secondary reactions, and the larger selectivity of this species could be related to the large formation of iso-butene.

Note that the formation of acetic and propanoic acids, species the formation of which is rarely reported in oxidation studies likely because of the low sensitivity of flame ionization detectors for this type of species, were observed in the oxidation of $n$-hexane and the two methyl-pentane isomers (Figures 10 and 11 ). Note that no acid formation was observed for 2,2-dimethyl-butane. Significant amounts of ketene were detected with $n$-hexane and 3-methyl-pentane (Figure 11). Mole fractions (with a maximum around $10^{-3}$ ) were deduced from the signal recorded for $m / z 42$ at $10.5 \mathrm{eV}$ by subtracting the contribution of propene (deduced from gas chromatography data). The cross section used for the quantification is $24.83 \mathrm{Mb}$ at $10.5 \mathrm{eV}$ (47).

It can also be seen that mole fraction profiles of some small hydrocarbons, such as methane, acetylene, and ethane, are very similar for all isomers over the common whole range of temperature (Figure 8). Note that allene and propyne, two unsaturated species which are known to play a role in the formation of soot, are formed in larger amounts with the branched alkanes (Figure 8) above $800 \mathrm{~K}$.

\subsection{Evolution of the Mole Fractions of Cyclic Ethers and Large Alkenes}

Cyclic ethers are species which are formed in relatively large quantities during the low-temperature oxidation of alkanes, whereas their formation is more difficult from alkenes.(27) The ways of formation of these cyclic oxygenated species are now well-established $(22,23)$ : they are produced from the reactions of addition of alkyl radicals to $\mathrm{O}_{2}$ followed by isomerization and decomposition reactions. The numerous possibilities of isomerizations and decompositions (into three, four, five, or six-membered ring cyclic ethers) are the reason for the numerous possible isomers of cyclic ethers formed during the low-temperature oxidation of alkanes. As an example, the formation of eight $\mathrm{C}_{6} \mathrm{H}_{12} \mathrm{O}$ cyclic ethers is expected for $n$-hexane, with some of them present twice because of the cis/trans conformation of the side alkyl groups (Table 2). As an example, the sequence of reactions forming 2,5-dimethyl-oxolane (also named 2,5-dimethyl-tetrahydrofuran) from $n$-hexane is displayed in Figure 14. Reaction 1 is a $\mathrm{H}$-atom abstraction forming an alkyl radical (2-hexyl radical in the example of Figure 14). This radical adds to $\mathrm{O}_{2}$ to form a 2-peroxyhexyl radical (reaction (2)) which reacts by isomerization (3) to form an hydroperoxyhexyl radical (the 2-hydroperoxy-hex-5-yl radical in the example of Figure 14). This last radical decomposes to yield a cyclic ether and an $\mathrm{OH}$ radical.

Due to the relatively high initial concentration and reactivity of this fuel, almost all expected isomers were identified (Table 2 and Figure 15). Four- and five-membered ring cyclic ethers (also called oxetanes and oxolanes, respectively) were formed in larger quantities than three- and six-membered ring cyclic ethers (also called oxiranes and oxanes, respectively). Note that the formation of three-membered ring cyclic ethers is rarely reported in JSR oxidation studies, likely due to too low inlet fuel mole fractions (e.g., ref 48). The identification of cyclic ethers was relatively easy because most of their electron impact $(70 \mathrm{eV})$ mass spectra are available in the NIST08 database. When mass spectra were not available in the NIST08 database, experimental ones were deciphered by looking for characteristic fragments (49) (see Figures S10 to S17). 
Table 2. List of Three- To Six-Membered Ring Cyclic Ethers Which Can Be Formed in the Low-Temperature Oxidation of $n$-Hexane.

\begin{tabular}{|c|c|c|c|}
\hline Name & Structure & $\begin{array}{l}\text { Number of possible } \\
\text { isomers }\end{array}$ & $\begin{array}{l}\text { Species detected } \\
\text { in this study }\end{array}$ \\
\hline 2-butyl-oxirane & & 1 & yes \\
\hline 2-propyl,3-methyl-oxirane & & 2 & $\begin{array}{l}\text { only one of the } \\
\text { two isomers }\end{array}$ \\
\hline 2,3-diethyl-oxirane & & 2 & $\begin{array}{l}\text { only one of the } \\
\text { two isomers }\end{array}$ \\
\hline 2-propyl-oxetane & & 1 & yes \\
\hline 2-ethyl,4-methyl-oxetane & & 2 & $\begin{array}{l}\text { the two isomers } \\
\text { were detected }\end{array}$ \\
\hline $\begin{array}{l}\text { 2-ethyl-oxolane (also named 2- } \\
\text { ethyl-tetrahydrofuran) }\end{array}$ & & 1 & yes \\
\hline $\begin{array}{l}\text { 2,5-dimethyl-oxolane (also } \\
\text { named 2,5-dimethyl- } \\
\text { tetrahydrofuran) }\end{array}$ & & 2 & $\begin{array}{l}\text { the two isomers } \\
\text { were detected }\end{array}$ \\
\hline $\begin{array}{l}\text { 2-methyl-oxane (also named 2- } \\
\text { methyl-tetrahydropyran) }\end{array}$ & & 1 & yes \\
\hline
\end{tabular}

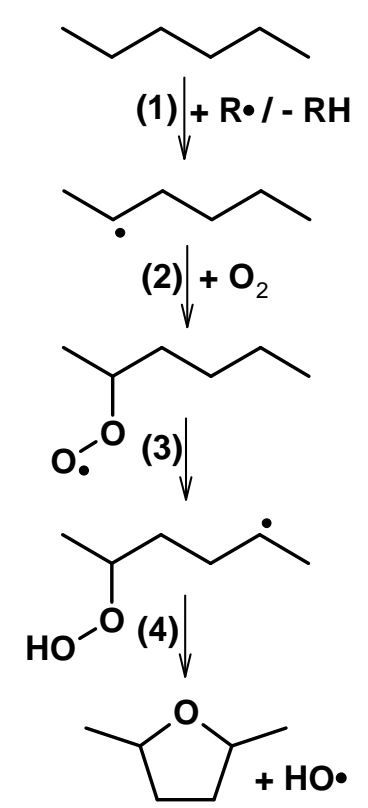

Figure 14. Route of formation of the cyclic ether 2,5-dimethyl-tetrahydrofuran from $n$-hexane. (1) $\mathrm{H}$ atom abstraction from the reactant; (2) addition to oxygen; (3) isomerization; and (4) decomposition into cyclic ether and the $\mathrm{OH}$ radical. 

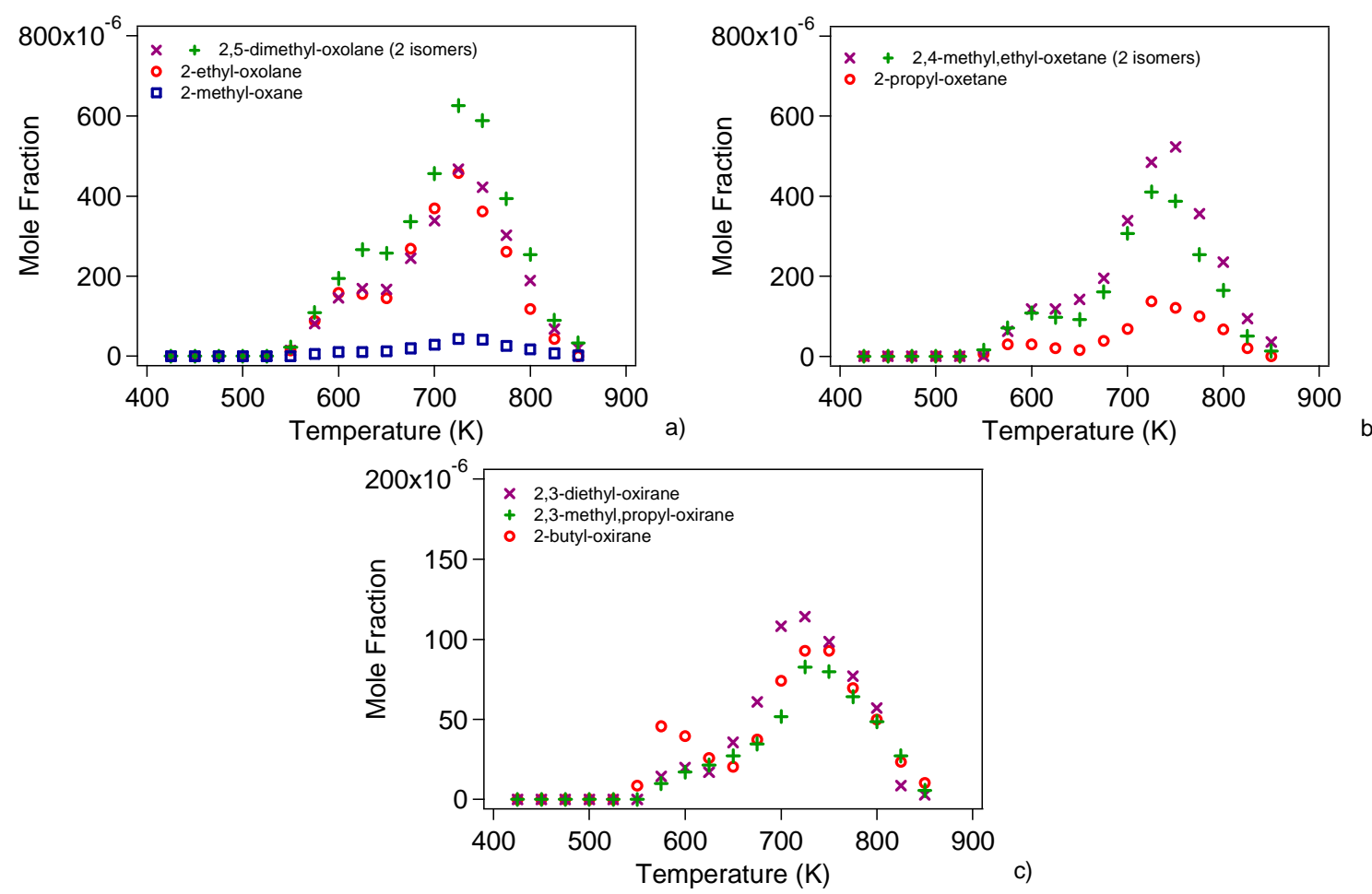

Figure 15. Mole fraction profiles of cyclic ethers obtained in the low-temperature oxidation of $n$-hexane (fuel inlet mole fraction of 0.02). (a) Five- and six-membered ring cyclic ethers. (b) Four-membered ring cyclic ethers. (c) Three-membered ring cyclic ethers. Mole fractions were obtained using gas chromatography.

Expected cyclic ethers for 2-methyl-pentane, 3-methyl-pentane, 2,2-dimethyl-butane, and 2,3-dimethyl-butane are shown in Tables 3, 4, 5, and 6, respectively. Mole fraction profiles are displayed in Figures 16 and 17. With $n$-hexane, 2,2-dimethyl-butane, and 2,3-dimethyl-butane as fuels, all expected cyclic ethers were detected. However, that was not the case for 2-methyl-pentane and 3-methyl-pentane. As an example, all the expected cyclic ethers, except all the oxiranes and one oxetane, were detected with 3 -methyl-pentane. There is no obvious reason which explains the missing cyclic ethers in the case of 2-methyl-pentane and 3-methyl-pentane. This could be due to the presence of competitive consumption routes such as the decomposition to a $\mathrm{HO}_{2}$ radical and an olefin, which is competitive with the decomposition into an oxirane and an $\mathrm{OH}$ radical. This competition would be favored in methyl-substituted reactants. However, no obvious evidence of this competition can be deduced from the mole fraction profiles of $C_{6}$ olefins shown in Figure 18.

Figure 19a displays the evolution between 500 and $750 \mathrm{~K}$ of the signals recorded using SVUV-PIMS for $m / z$ 100 , which corresponds to $\mathrm{C}_{6} \mathrm{H}_{12} \mathrm{O}$ species (cyclic ethers, hexanal, and hexanones). This signal is the sum of the contributions of each $\mathrm{C}_{6} \mathrm{H}_{12} \mathrm{O}$ isomers, and the extraction of mole fractions was not carried out due to their similar ionization energies and a lack of data for cross sections for these species. Signal intensities are very similar for $n$-hexane and methyl-pentane isomers but much lower for 2,2-dimethyl-butane. Figure $19 \mathrm{~b}$ presents the sum of $\mathrm{C}_{6} \mathrm{H}_{12} \mathrm{O}$ species obtained by $\mathrm{GC}$ analyses. This confirms that despite the much larger reactivity for $n$-hexane than for other fuels (as shown in Figure 7), the sum of the mole fractions of $\mathrm{C}_{6} \mathrm{H}_{12} \mathrm{O}$ species (which are mostly cyclic ethers) at $650 \mathrm{~K}$ is the highest for 2-methyl-pentane and similar for $n$-hexane, 3-methyl-pentane, and 2,2-dimethyl-butane. This clearly shows that the formation of cyclic ethers is significantly favored from branched alkanes below $650 \mathrm{~K}$. This is in agreement with theoretical work of Wijaya et al. (50). These calculations showed that methyl substitution reduces the barrier height for the formation 
of oxetanes and oxiranes, with little effect on oxolanes, because of the release of alkyl strain in the cyclic transition state. In the NTC area, the cyclic ether formation from $n$-hexane is the largest because it is the only fuel isomer with a significant reactivity in this zone.

Table 3. List of Three- To Six-Membered Ring Cyclic Ethers Which Can Be Formed during the LowTemperature Oxidation of 2-Methyl-Pentane.

\begin{tabular}{|c|c|c|c|}
\hline Name & Structure & $\begin{array}{l}\text { Number of possible } \\
\text { isomers }\end{array}$ & $\begin{array}{l}\text { Species detected in } \\
\text { this study }\end{array}$ \\
\hline 2,2-methyl,propyl-oxirane & & 1 & no \\
\hline 2,2-dimethyl,3-ethyl-oxirane & & 1 & yes \\
\hline 2-methyl,3-isopropyl-oxirane & & 2 & no \\
\hline 2-isobutyl-oxirane & & 1 & no \\
\hline 3-propyl-oxetane & & 1 & yes \\
\hline 2-ethyl,3-methyl-oxetane & & 2 & no \\
\hline 2,2,4-trimethyl-oxetane & & 1 & yes \\
\hline 2-isopropyl-oxetane & & 1 & yes \\
\hline $\begin{array}{l}\text { 2,2-dimethyl-oxolane (also } \\
\text { named 2,2-dimethyl- } \\
\text { tetrahydrofuran) }\end{array}$ & & 1 & yes \\
\hline $\begin{array}{l}\text { 2,4-dimethyl-oxolane (also } \\
\text { named 2,4-dimethyl- } \\
\text { tetrahydrofuran) }\end{array}$ & & 2 & $\begin{array}{l}\text { the two isomers } \\
\text { were detected }\end{array}$ \\
\hline $\begin{array}{l}\text { 3-methyl-oxane (also named 3- } \\
\text { methyl-tetrahydropyran) }\end{array}$ & & 1 & no \\
\hline
\end{tabular}

The formation of cyclic ethers has already been reported by Dagaut et al. during the oxidation of $n$-heptane, iso-octane, and $n$-decane (51-53). All tetrahydrofuran isomers were identified in these studies (cis and trans 2-methyl-5-ethyl-tetrahydrofuran, 2-propyl-tetrahydrofuran, and 2,2,4,4-tetramethyl-tetrahydrofuran in the $n$-heptane and iso-octane studies $(51,52)$; cis- and trans-2,5-dipropyl-tetrahydrofuran, cis- and trans-2-ethyl5-butyl-tetrahydrofuran, cis- and trans-2-methyl-5-pentyl-tetrahydrofuran, and 2-hexyl-tetrahydrofuran in the $n$-decane study (53)). While not reporting all the possible isomers, Dagaut et al. also observed the formation of some oxetanes and oxiranes during the oxidation of $n$-heptane and iso-octane $(51,52)$ (cis- and 
trans-2-methyl-4-propyl-oxetane, 2-ethyl-3-propyl-oxirane, cis-2-methyl-3-butyl-oxirane, 2-iso-propyl-3,3dimethyl-oxetane, 2-terbutyl-3-methyl-oxetane, 2,4-diethyl-oxetane, and 2-methyl-3-butyl-oxirane). In the studies about the oxidation of some $\mathrm{C}_{8} \mathrm{H}_{18}$ isomers, Sarathy et al. $(19,21)$ and Karsenty et al. $(20)$ observed the formation of only a few five membered ring cyclic ethers (oxolanes), whereas all possible isomers were detected in the present hexane isomer study. As an example, the only five-membered ring cyclic ether detected during the oxidation of 3-methyl-heptane (20) was 2,5-dimethyl-2-ethyl-tetrahydrofuran, whereas the formation of five other isomers could be expected. In accordance with the flow rate analysis presented in ref 20, non-negligible amount of 2-butyl-2-methyl-oxetane would be formed during this reaction, but the detection of this species was not reported during those experiments. Note that these studies were performed with lower initial fuel mole fractions than in the present work, yielding lower reaction product concentrations and inducing then difficulties to detect them.

Table 4. List of Three- To Six-Membered Ring Cyclic Ethers Which Can Be Formed during the LowTemperature Oxidation of 3-Methyl-Pentane.

(2-methyl),2-propyl-oxirane
$\begin{aligned} & \text { 2,2-methyl,ethyl,3-methyl- } \\ & \text { oxirane }\end{aligned}$


Table 5. List of Three- To Five-Membered Ring Cyclic Ethers Which Can Be Formed during the LowTemperature Oxidation of 2,2-Dimethyl-butane.

\begin{tabular}{lll}
\hline Name & Sumber of possible & $\begin{array}{l}\text { Species detected in } \\
\text { isomers } \\
\text { this study }\end{array}$ \\
\hline $\begin{array}{l}\text { 3,3-dimethyl-oxolane (also } \\
\text { named 3,3-dimethyl- } \\
\text { tetrahydrofuran) }\end{array}$ & 1 & yes \\
3,3-methyl-ethyl-oxetane
\end{tabular}

Table 6. List of Three- To Five-Membered Ring Cyclic Ethers Which Can Be Formed during the LowTemperature Oxidation of 2,3-Dimethyl-butane.

Name
$\begin{aligned} & \text { 3-isopropyl-oxetane } \\ & \text { 3,4-dimethyl-oxolane (also } \\ & \text { named) 3,4-dimethyl- } \\ & \text { tetrahydrofuran }\end{aligned}$



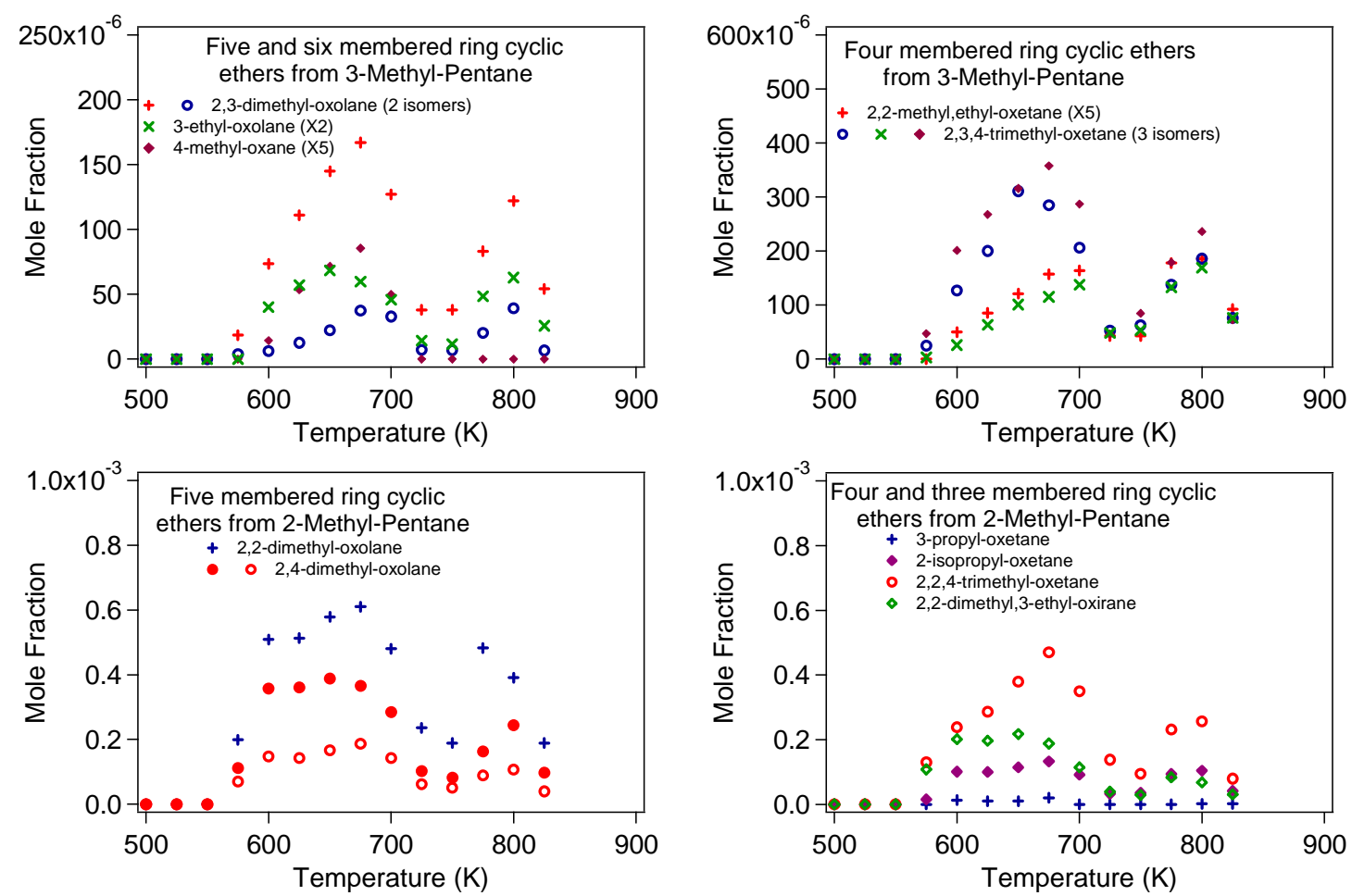

Figure 16. Mole fraction profiles of cyclic ethers obtained in the low-temperature oxidation of 2-methylpentane and 3-methyl-pentane (fuel inlet mole fraction of 0.02). Mole fractions were obtained using gas chromatography. Mole fractions of species formed in small amounts were multiplied by a factor $\alpha(\times \alpha)$ to better see their profiles.
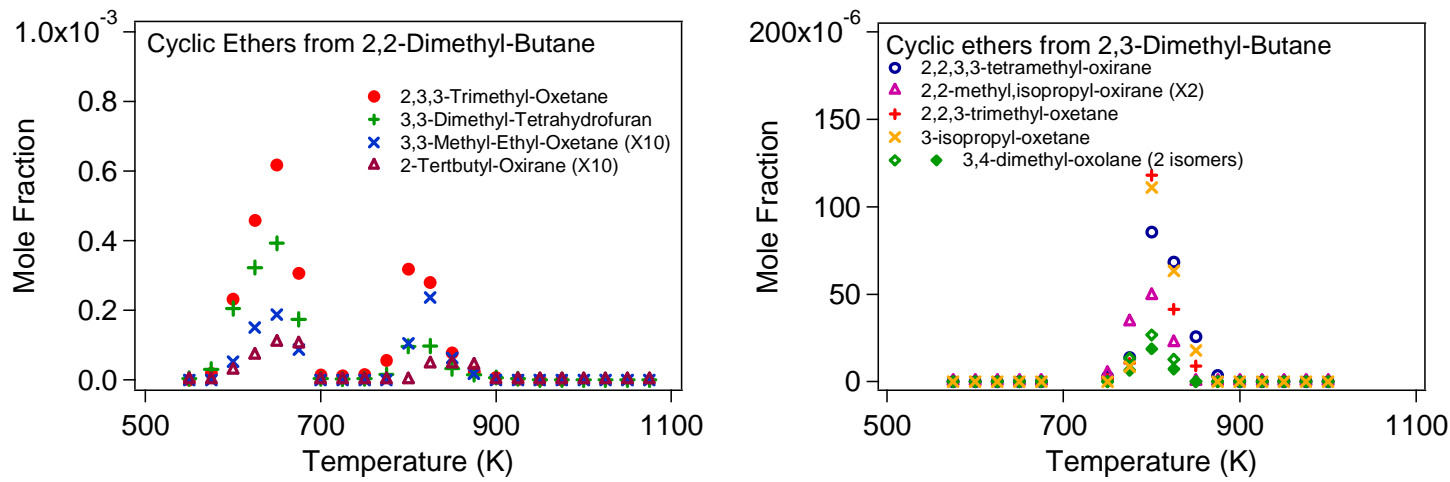

Figure 17. Mole fraction profiles of cyclic ethers obtained in the low-temperature oxidation of

2,2-dimethyl-butane and 2,3-dimethyl-butane (fuel inlet mole fraction of 0.02). Mole fractions were obtained using gas chromatography. Mole fractions of species formed in small amounts were multiplied by a factor $\alpha(\times \alpha)$ to better see their profiles. 

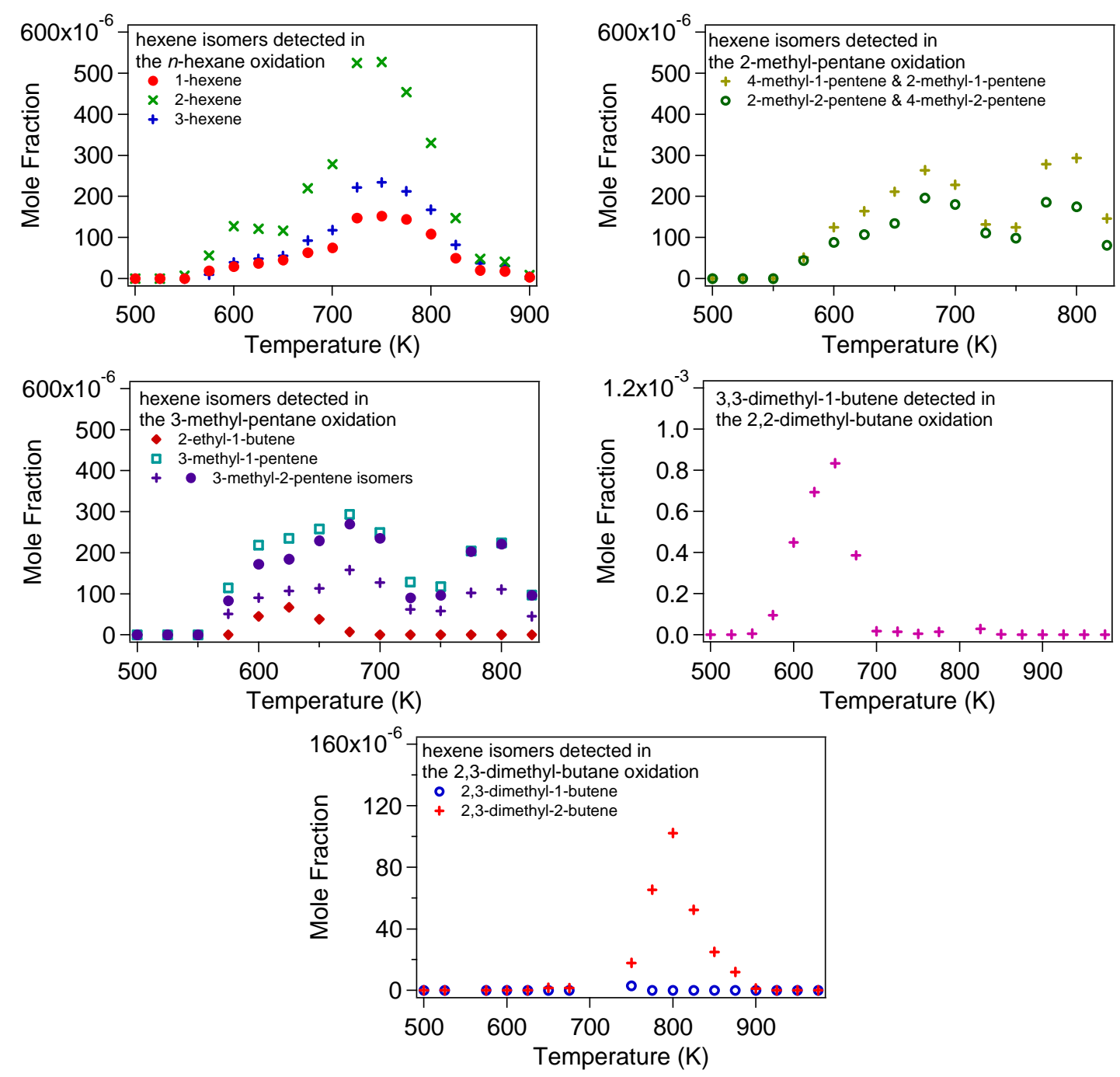

Figure 18. Mole fractions of $\mathrm{C}_{6} \mathrm{H}_{12}$ isomers detected during the oxidation of hexane isomers (gas chromatography data). Data were obtained for an initial fuel mole fraction of 0.02 .
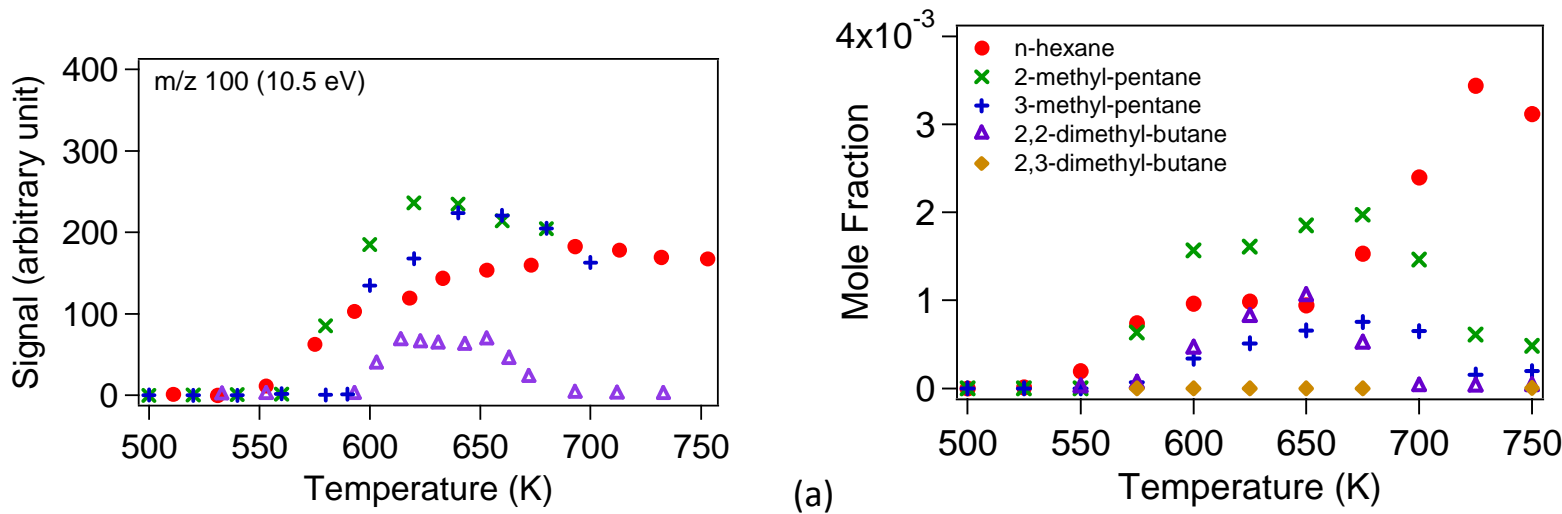

Figure 19. (a) Signals at $\mathrm{m} / \mathrm{z} 100$ [corresponding to $\mathrm{C}_{6} \mathrm{H}_{12} \mathrm{O}$ species (cyclic ethers, hexanal, and hexanones)] obtained using SVUV-PIMS and (b) the sum of the $\mathrm{C}_{6} \mathrm{H}_{12} \mathrm{O}$ species obtained by GC (fuel inlet mole fraction of $0.02)$.

Alkenes of the same size as the reactant are also important products in the low-temperature oxidation of hydrocarbons. They can be formed by $\mathrm{H}$-abstraction of $\mathrm{O}_{2}$ from alkyl radicals produced from the reactant or by $\mathrm{HO}_{2}$ elimination from $\mathrm{RO}_{2}$ radicals. The structures of the $\mathrm{C}_{6}$ alkenes detected during this study are listed in 
Table 7, and the mole fraction profiles are given in Figure 18 for the five hexane isomers. Note that the formation of 2-hexene is favored from $n$-hexane, since it can be obtained from alkyl radicals formed by the abstraction of four secondary $\mathrm{H}$ atoms. All the hexene isomers could not be separated in the GC analysis for 2-methyl-pentane. 3,3-Dimethyl-1-butene is formed in very large amounts since it is the only alkene that can be produced from 2,2-dimethyl-butane. Since 2,3-dimethyl-butane is unreactive at lower temperature, alkene formation is only observed from $750 \mathrm{~K}$. The production of alkenes from alkyl radicals obtained by the abstraction of the two tertiary $\mathrm{H}$ atoms is much favored.

Table 7. Structures of $\mathrm{C}_{6} \mathrm{H}_{12}$ Isomers Detected during the Oxidation of Hexane Isomers.

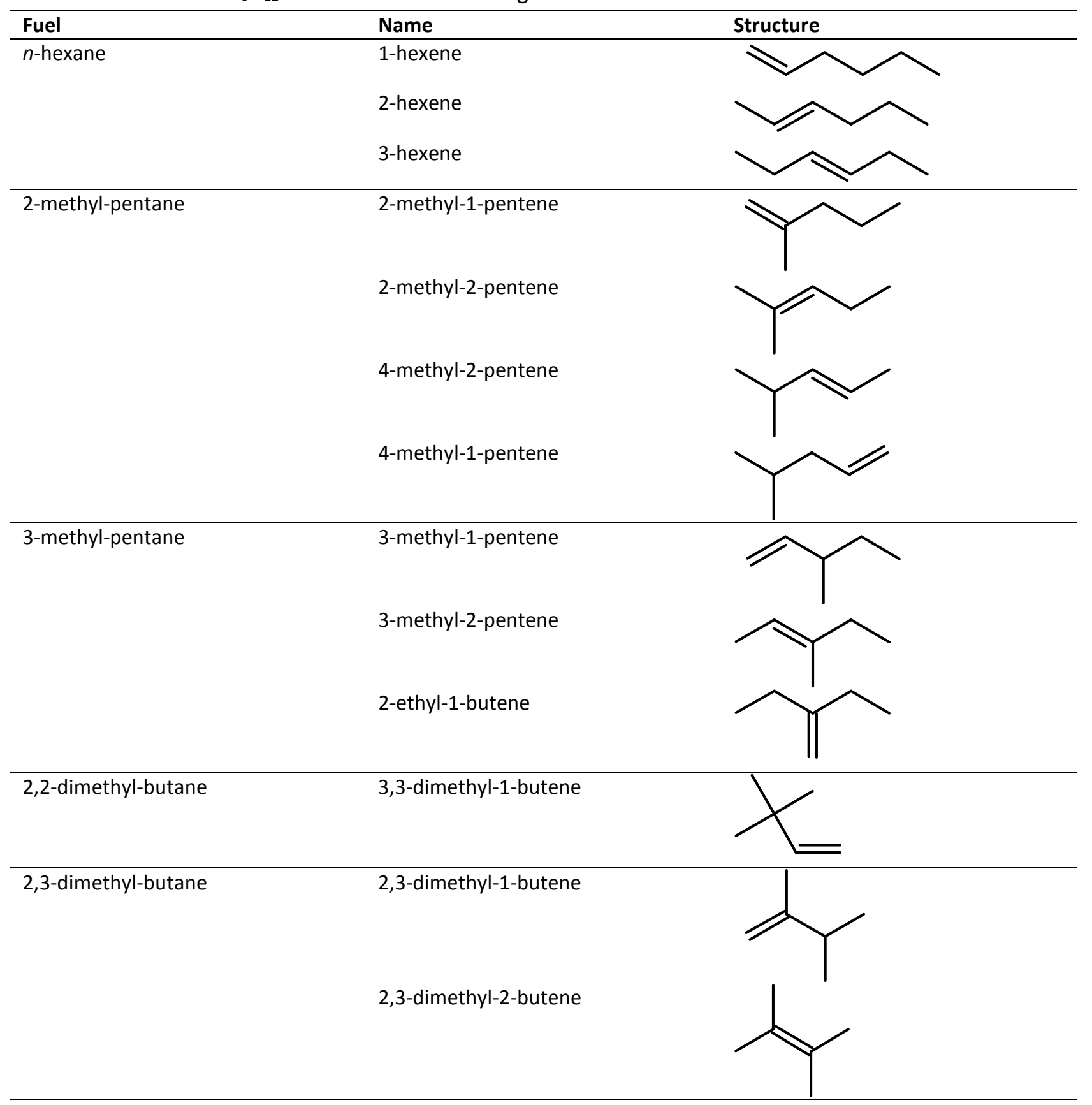

\subsection{Evolution of the Mole Fractions of Diones and Ketohydroperoxides}

In line with our previous studies on linear alkanes ( $n$-butane (34) and $n$-heptane (32)), we have recorded here signals which can potentially correspond to ketohydroperoxides and diones (for simplification, aldo- and keto-hydroperoxides are gathered in the generic term of ketohydroperoxides). Note that contrary to the case 
of $n$-butane, no signal corresponding to other hydroperoxides was recorded. Figure 20 displays the signals obtained using SVUV-PIMS for $\mathrm{m} / \mathrm{z} 114,116$, and 132. Note that the data obtained during the 2,3-dimethyl-butane oxidation study are not presented here because of the lack of reactivity of this species under the conditions of the study performed in Hefei (fuel inlet mole fraction of 0.02). The $m / z 114,116$, and 132 mainly corresponds to $\mathrm{C}_{6} \mathrm{H}_{10} \mathrm{O}_{2}$ species (species with two carbonyl groups, called diones in this paper), to $\mathrm{C}_{6} \mathrm{H}_{12} \mathrm{O}_{2}$ species and to $\mathrm{C}_{6} \mathrm{H}_{12} \mathrm{O}_{3}$ species (ketohydroperoxides), respectively.
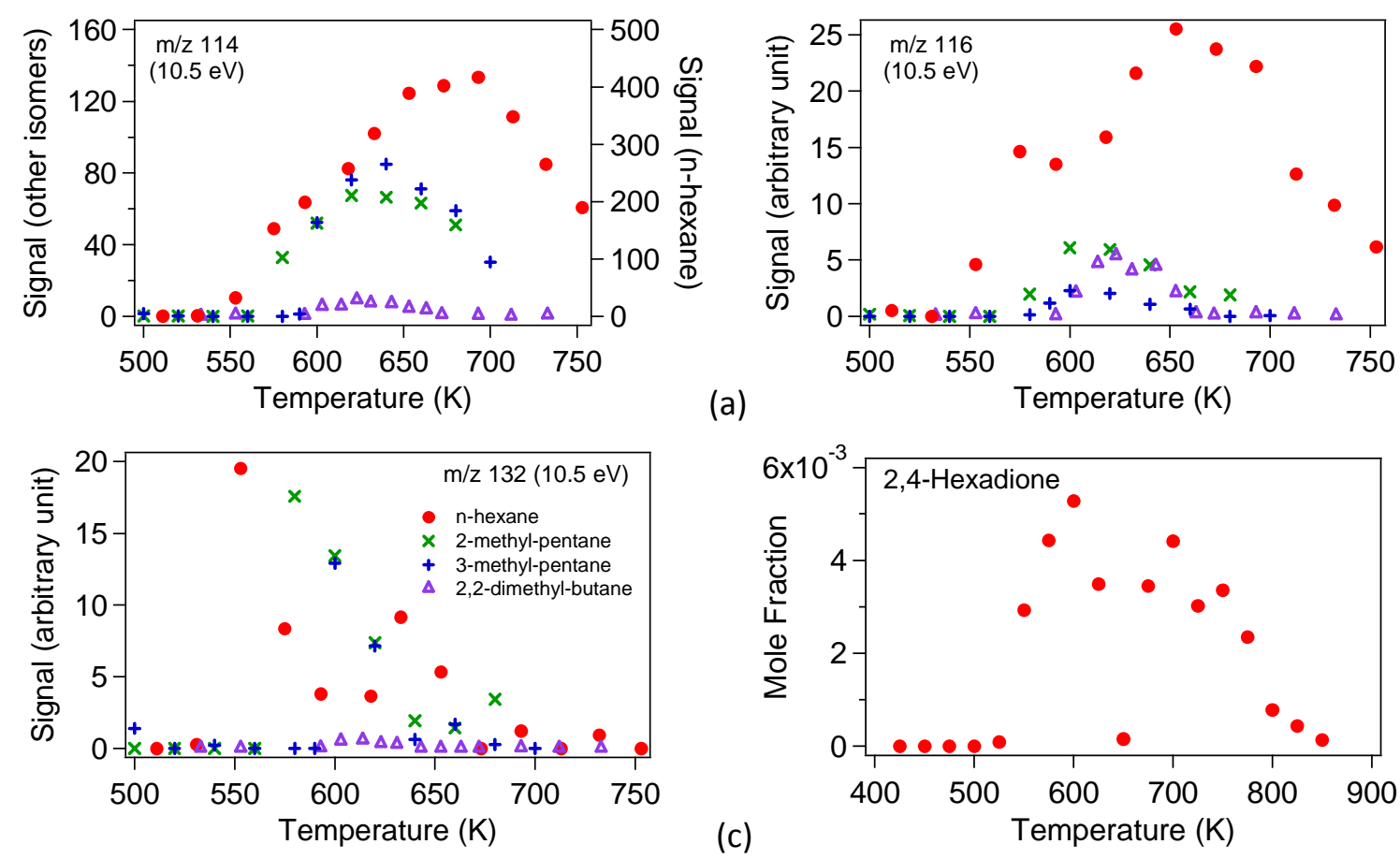

(a)

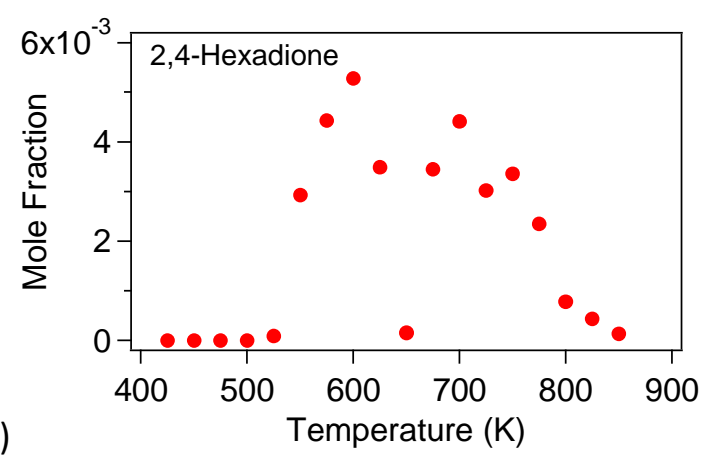

(b)

Figure 20. (a-c) Comparison of the signals for $m / z$ 114, 116, and 132 obtained using SVUV-PIMS. $m / z 114$, 116 , and 132 mainly corresponds to $\mathrm{C}_{6} \mathrm{H}_{10} \mathrm{O}_{2}$ species (diones), $\mathrm{C}_{6} \mathrm{H}_{12} \mathrm{O}_{2}$ species (with a carbonyl and an alcohol functions), and $\mathrm{C}_{6} \mathrm{H}_{12} \mathrm{O}_{3}$ species (ketohydroperoxides), respectively. (d) Mole fraction profile of 2,4-hexadione obtained by gas chromatography in the $n$-hexane study (fuel inlet mole fraction of 0.02 ).

The signal at $m / z 132$ mainly corresponds to ketohydroperoxides formed during low-temperature branching chain reactions. As previously shown for $n$-butane (34) and $n$-heptane (32), the signal of this type of species exhibits a sharp peak in the early reactivity zone (Figure 20c). The more reactive the fuel, the lower the temperature for the location of the peak: for $n$-hexane, which is the most reactive fuel, the peak is located at only $550 \mathrm{~K}$. For the two methyl-pentane isomers, peaks can be seen between 580 and $600 \mathrm{~K}$. Finally, for 2,2-dimethyl-butane, the peak is near $620 \mathrm{~K}$. This clearly demonstrates how the formation of ketohydroperoxides, a type of species the formation of which was postulated in detailed kinetic models a long time ago but was only recently experimentally confirmed under conditions close to those prior to ignition in engines (54), is controlling the reactivity of hydrocarbons. Note that the signal at $\mathrm{m} / \mathrm{z} 132$ for 2,2-dimethyl-butane is about 30 times lower than that of other isomers. This agrees with the fact that the formation of ketohydroperoxides, species deriving from $\mathrm{O}_{2}$ additions by a series of two isomerizations, is hindered for highly branched species.

The identification of diones and ketohydroperoxides detected using SVUV-PIMS was performed by comparing the energy thresholds in the photoionization efficiency spectra obtained at $m / z 114$ and 132 for the four reactive isomers (shown in Figure 21) to theoretical ionization energies of the most probable species (given in Tables 8 and 9). Since there is no data for $C_{6}$ ketohydroperoxides and diones in the literature, zero- 
point energy corrected adiabatic ionization energies (IEs) have been calculated from the composite CBS-QB3 method (55) using Gaussian03 (56). For each species, we tried to perform geometry optimization starting from the lowest energy conformer. However, a very high number of rotational conformers exist for each species and its exact localization on the potential energy surface can be difficult. For ketohydroperoxides, the lowest energy conformer can usually be obtained by considering the hydrogen bonds in the initial geometry. Only the structures of the most probable (from a kinetic point of view, see explanations in the next paragraph) $C_{6}$ ketohydroperoxides and diones are presented in Tables 8 and 9 , together with the calculated ionization energies. The calculated structure of the related parent cations are presented in Tables S1 and S2 of the Supporting Information.

\section{Kinetic Origin of the Major Ketohydroperoxides}

From a kinetic point of view, the position of the two functional groups (carbonyl and hydroperoxide groups) in ketohydroperoxides formed during alkane oxidation is imposed by the location of the initial $\mathrm{H}$-abstraction from the reactant to form an alkyl radical (reaction 1 in Figure 14) and by the first isomerization of the peroxyalkyl radical (reaction (3) in Figure 14) obtained by the addition to oxygen of this alkyl radical [reaction (2) in Figure 14]. The most probable ketohydroperoxide isomers which can be formed are then those with the two carbon atoms carrying the two functional groups separated by another carbon atom. This is due to the fact that the easiest isomerizations are those involving transition states with a 6- or a 7-membered ring with a ring stain energy of 8 and $5 \mathrm{kcal} / \mathrm{mol}$, respectively (54). Besides, for isomerizations involving transition states with a 7-membered ring, the obtained hydroperoxyalkyl radicals preferably decompose to oxolanes as shown in Figure 14, whereas, in the case of the isomerizations involving transition states with a 6-membered ring, the obtained hydroperoxyalkyl radicals preferably add to $\mathrm{O}_{2}$ (second addition not shown in Figure 14) to form in fine ketohydroperoxides. This explains why diones, which are most probably species derived from ketohydroperoxides, are mainly those with the carbon atoms carrying the two carbonyl groups separated by another carbon atom. This is confirmed by the structure of the only dione detected by GC analyses: 2,4-hexadione, during $n$-hexane oxidation, as shown in Figure $20 \mathrm{~d}$. A similar observation was made during $n$-heptane oxidation (32), where the identified diones were the 2,4-heptadione and 3,5-heptadione.

\section{Identification of Ketohydroperoxides ( $\mathrm{m} / \mathrm{z}$ 132)}

For $n$-hexane, the experimental ionization energy (IE) corresponding to $m / z 132$ is around 9.2-9.3 eV (see Figure 21), which is close to that calculated for the four envisaged structures (from 9.20 to $9.53 \mathrm{eV}$, see Table 8). In the following analysis, we will consider that the main ketohydroperoxides obtained from $n$-hexane are the two ketones (4-hydroperoxyhexan-2-one and 5-hydroperoxyhexan-3-one), which can be obtained from the $\mathrm{H}$-atom abstractions and isomerizations involving only secondary $\mathrm{H}$-atoms (the formation of aldohydroperoxides is disfavored to a kinetic point of view because it involves the abstraction of primary $\mathrm{H}$-atoms, which are less labile than secondary ones).

For 2-methyl-pentane, the experimental IE is around $9.05 \mathrm{eV}$, which is close to the calculated value for 2-methyl-3-hydroperoxy pentanal $(9.10 \mathrm{eV})$. The formation of this ketohydroperoxide is favored since it can be obtained from the abstractions of 6 primary (by $\mathrm{H}$ atom abstraction) and 2 secondary (by isomerization) $\mathrm{H}$ atoms. Note, however, that from a kinetic point of view, another favored ketohydroperoxide would be 4-methyl-4-hydroperoxypentan-2-one. This last compound can be obtained from the abstractions of two secondary (by $\mathrm{H}$ atom abstraction) and one tertiary (by isomerization) $\mathrm{H}$ atoms. 
For 3-methyl-pentane, the experimental IE is around $9.15 \mathrm{eV}$, clearly showing that the most probable ketohydroperoxide is 3-methyl-4-hydroperoxy-pentan-2-one (calculated IE $=9.18 \mathrm{eV}$ ). The formation of this species can be derived from the six secondary $\mathrm{H}$ atom abstractions (4 by $\mathrm{H}$-abstraction due to the symmetry of the reactant molecule and 2 by isomerization).
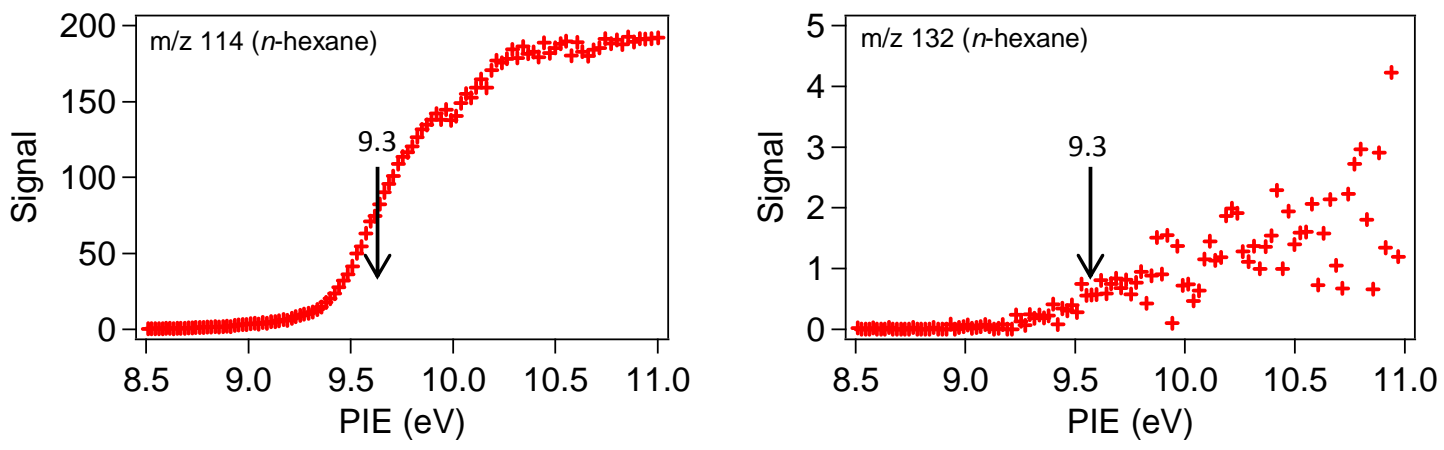

(a)
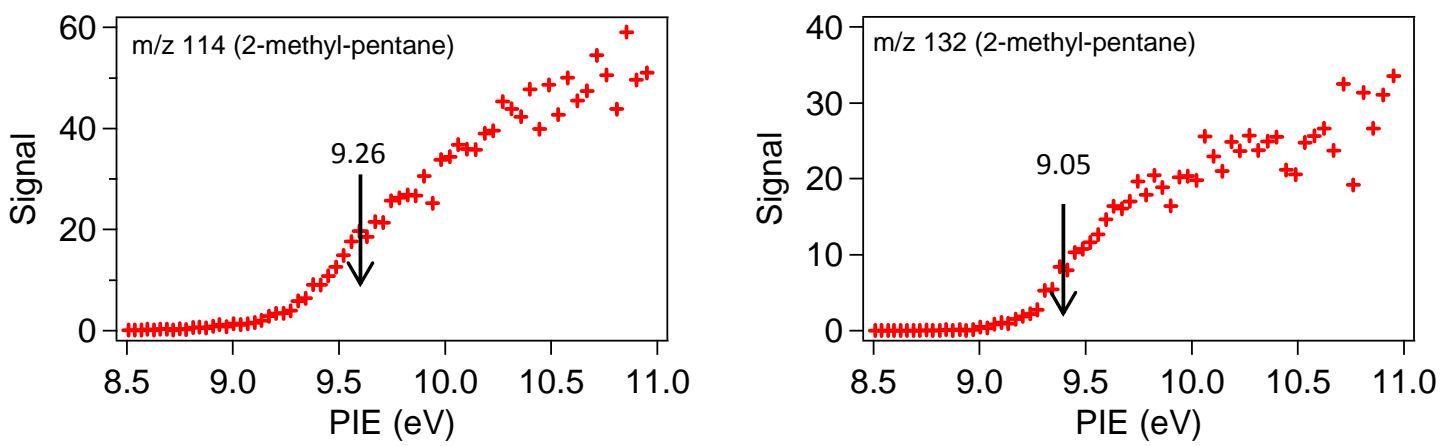

(b)
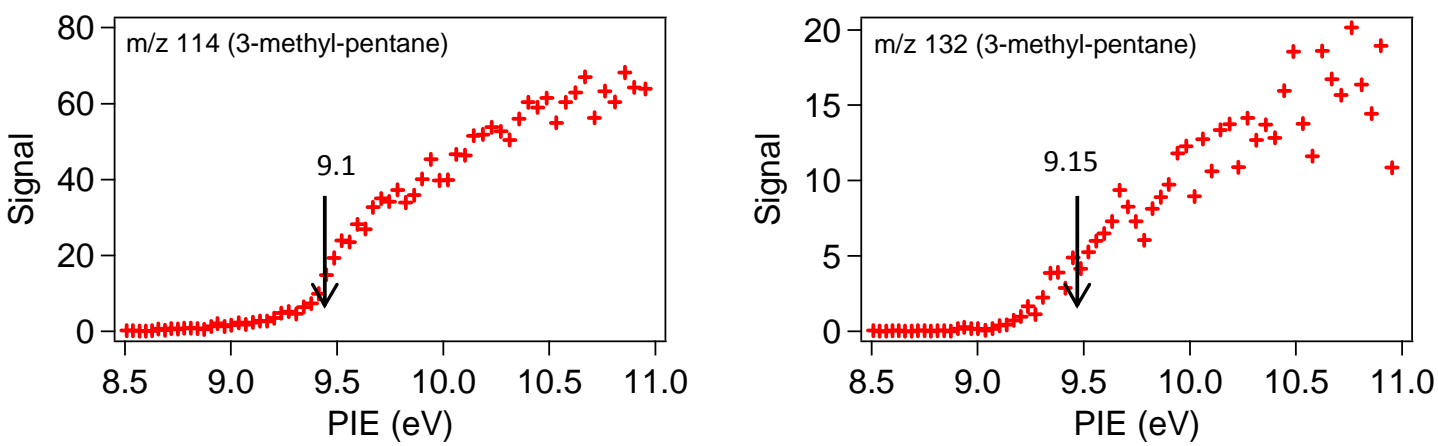

(c)
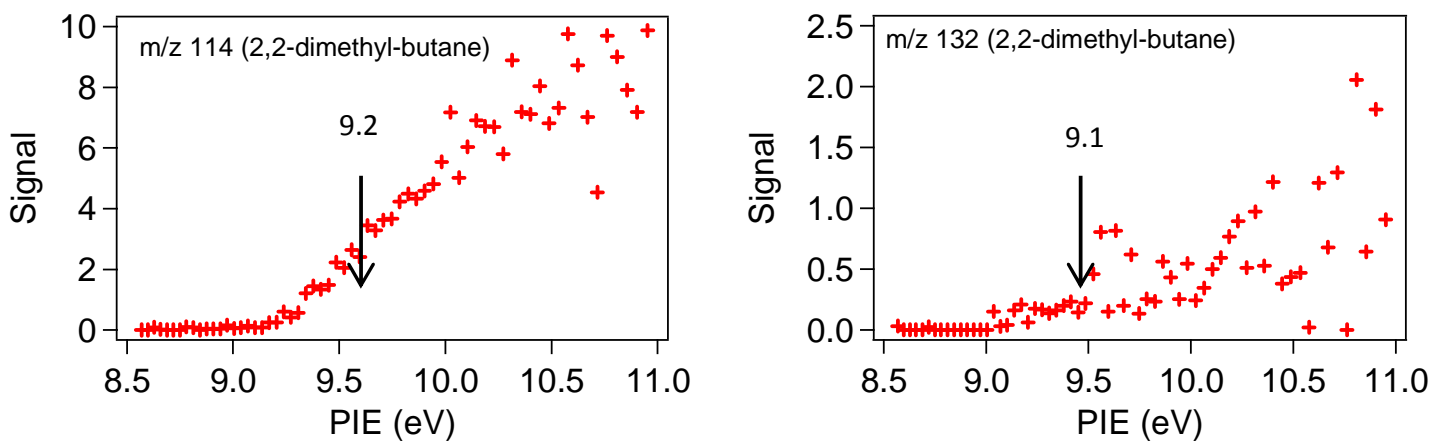

(d)

Figure 21. Photoionization efficiency spectra (a.u.) of $\mathrm{m} / \mathrm{z} 114$ and 132 sampled from the reactor during the oxidation of (a) $n$-hexane, (b) 2-methyl-pentane, (c) 3-methyl-pentane, and (d) 2,2-dimethyl-butane.

Temperatures in the reactor were $653,620,620$, and $623 \mathrm{~K}$, respectively. The arrows indicate the assumed locations of the thresholds. 
Table 8. Structures and Calculated Ionization Energies of the Most Probable Ketohydroperoxides Which Can Be Formed during the Oxidation of Hexane Isomers. The values in bold correspond to the most probable species according to a kinetic analysis.

\begin{tabular}{|c|c|c|}
\hline Name & Structure & $\begin{array}{c}\text { Calculated } \\
\text { ionization energy }(\mathrm{eV}) \\
\end{array}$ \\
\hline \multicolumn{3}{|c|}{ From $n$-hexane } \\
\hline 4-hydroperoxyhexan-2-one & & 9.20 \\
\hline 5-hydroperoxyhexan-3-one & & 9.50 \\
\hline 1-hydroperoxyhexan-3-one & & 9.53 \\
\hline 3-hydroperoxyhexanal & & 9.49 \\
\hline \multicolumn{3}{|c|}{ From 2-methyl-pentane } \\
\hline $\begin{array}{l}\text { 4-methyl- } \\
\text { 4-hydroperoxypentan-2-one }\end{array}$ & & 8.87 \\
\hline $\begin{array}{l}\text { 4-methyl- } \\
\text { 3-hydroperoxypentanal }\end{array}$ & & 9.53 \\
\hline $\begin{array}{c}\text { 4-methyl- } \\
\text { 1-hydroperoxypentan-3-one }\end{array}$ & & 8.95 \\
\hline 2-methyl-3-hydroperoxy pentanal & & 9.10 \\
\hline $\begin{array}{c}\text { 2-methyl-1-hydroperoxy pentan-3- } \\
\text { one }\end{array}$ & & 9.36 \\
\hline \multicolumn{3}{|c|}{ From 3-methyl-pentane } \\
\hline 3-methyl-3-hydroperoxy -pentanal & & 9.21 \\
\hline $\begin{array}{l}\text { 3-methyl-4-hydroperoxy -pentan-2- } \\
\text { one }\end{array}$ & & 9.18 \\
\hline 2-ethyl-3-hydroperoxybutanal & & 9.04 \\
\hline $\begin{array}{l}\text { 3-(hydroperoxymethyl)pentan-2- } \\
\text { one }\end{array}$ & & 9.26 \\
\hline
\end{tabular}


Table 8. Continued.

\begin{tabular}{|c|c|c|}
\hline Name & Structure & $\begin{array}{c}\text { Calculated } \\
\text { ionization energy (eV) }\end{array}$ \\
\hline $\begin{array}{c}\text { 2-(hydroperoxymethyl)-2- } \\
\text { methylbutanal }\end{array}$ & From 2,2-dimethyl-butane \\
\hline 2,2-dimethyl-3-hydroperoxybutanal & $\mathbf{9 . 1 2}$ \\
\hline $\begin{array}{c}\text { 3,3-dimethyl-4- } \\
\text { hydroperoxybutanone }\end{array}$ & $\mathbf{8 . 5 3}$ \\
\hline
\end{tabular}

Table 9. Structures and Calculated Ionization Energies of the Most Probable Diones that Can Be Formed during the Oxidation of Hexane Isomers. The values in bold correspond to the most probable species according to a kinetic analysis.

\begin{tabular}{|c|c|c|}
\hline Name & Structure & $\begin{array}{c}\text { Calculated } \\
\text { ionization energy }(\mathrm{eV})\end{array}$ \\
\hline \multicolumn{3}{|c|}{ From $n$-hexane } \\
\hline 2,4-hexadione & & 9.31 \\
\hline & & \\
\hline 3-oxo-hexanal & & 9.37 \\
\hline \multicolumn{3}{|c|}{ From 2-methyl-pentane } \\
\hline 4-methyl-3-oxo-pentanal & & 9.26 \\
\hline 2-methyl-3-oxo-pentanal & & 9.26 \\
\hline \multicolumn{3}{|c|}{ From 3-methyl-pentane } \\
\hline 3-methyl-2,4-pentadione & & 9.16 \\
\hline 2-ethyl-3-oxobutanal & & 9.23 \\
\hline \multicolumn{3}{|c|}{ From 2,2-dimethyl-butane } \\
\hline 2-ethyl-2methylpropanedial & & 9.31 \\
\hline 2,2-dimethyl-3-oxobutanal & & 9.13 \\
\hline
\end{tabular}


For 2,2-dimethyl-butane, the experimental IE is around $9.1 \mathrm{eV}$ corresponding to 2-(hydroperoxymethyl)-2methyl-butanal (calculated IE $=9.12 \mathrm{eV}$ ), which is a probable structure among those envisaged in Table 8, since it would be derived from the abstraction of 15 primary ( 9 by $\mathrm{H}$ atom abstraction and 6 by isomerization) $\mathrm{H}$ atoms. The formation of the two other ketohydroperoxides involving the abstraction of secondary $\mathrm{H}$ atoms cannot be excluded. Note however that the calculated IE $(9.33 \mathrm{eV})$ of one of these isomers, 3,3-dimethyl-4hydroperoxybutanone, is not very far from the experimental value and that the calculated value for the second isomer (i.e., 2,2-dimethyl-3-hydroperoxy-butanal) is much lower than the average obtained value due to the particular structure of its parent cation (the hydroperoxy group tends to be very close to the ketone group, see Table S1 of the Supplementary Material).

\section{Identification of Diones ( $\mathrm{m} / \mathrm{z}$ 114)}

For $n$-hexane at $\mathrm{m} / \mathrm{z} 114$, the experimental IE is around $9.3 \mathrm{eV}$ (see Figure 21), which is close to that calculated for 2,4-hexadione $(9.31 \mathrm{eV}$, see Table 9). This supports the fact that the two ketones of Table 8 (4-hydroperoxyhexan-2-one and 5-hydroperoxyhexan-3-one) are the most probable ketohydroperoxides deriving from $n$-hexane. In the case of 2-methyl-pentane, the experimental IE at $m / z 114$ is around $9.2 \mathrm{eV}$, which is in good agreement with the calculated IE $(9.26 \mathrm{eV})$ for both envisaged structures. Note that one of the most probable ketohydroperoxides cannot lead to diones since the hydroperoxy group is carried by a tertiary C-atom. For 3-methyl-pentane, the experimental IE at $\mathrm{m} / \mathrm{z} 114$ is around $9.1 \mathrm{eV}$, supporting the formation of the dione (3-methyl-2,4-pentadione) which can be derived from the most abundant ketohydroperoxide: 3-methyl-4-hydroperoxy-pentan-2-one. In the case of 2,2-dimethyl-butane for $\mathrm{m} / \mathrm{z}$ 114, the experimental IE is around $9.2 \mathrm{eV}$, which is close to the value calculated for 2,2-dimethyl-3-oxobutanal $(9.13 \mathrm{eV})$. This supports the fact that the two ketohydroperoxides (3,3-dimethyl-4-hydroperoxybutanone and 2,2-dimethyl-3-hydroperoxybutanal), the formation of which involves the abstraction of secondary $\mathrm{H}$ atoms, are also formed in significant amounts.

\section{Decomposition of Ketohydroperoxides}

Ketohydroperoxides can easily decompose by breaking of the fragile $\mathrm{O}-\mathrm{OH}$ bond, leading to alkoxy radicals, including a carbonyl group. These alkoxy radicals can decompose in several ways, which are discussed in the next paragraphs.

Alkoxy radicals can easily decompose by breaking of a $\mathrm{C}-\mathrm{C}$ bond (by $\beta$-scission decomposition). The main alkoxy radicals and the expected products from $n$-hexane and methyl-pentane isomers are shown in Figure 22. The expected products shown in Figure 22 are consistent with the largest amounts of acetaldehyde formed in the case of $n$-hexane and 3-methyl-pentane (see Figure 10), the largest amount of acetone formed from 2-methyl-pentane (see Figure 11), and the largest amounts of propanal formed in the case of $n$-hexane and 2-methyl-pentane (see Figure 11). Note that the very large formation of acetone obtained from 2-methylpentane can also be partly due to the large iso-butene formation obtained from this compound. In addition, acetic acid (which will be discussed further in this paragraph), acetaldehyde, acetone, and propanal are the major $\mathrm{C}_{2}-\mathrm{C}_{3}$ species produced below $650 \mathrm{~K}$. Note that 1-methylvinoxy radicals $\left(\mathrm{CH}_{3}-\mathrm{CO}-\mathrm{CH}_{2} \bullet\right)$ formed from $n$-hexane and 3-methyl-pentane can be a source of ketene $\left(\mathrm{CH}_{2} \mathrm{CO}\right)$. For 2,2-dimethyl-butane, the decomposition of the three envisaged ketohydroperoxides would mainly be a source of formaldehyde and acetaldehyde, but for this reactant, it is difficult to explain the large observed acetone formation only from the ketohydroperoxide decompositions. 
Alkoxy radicals from main ketohydroperoxides from $n$-hexane<smiles>CCC([O])CC(C)=O</smiles><smiles>C1CC1</smiles><smiles>CC(C)=O</smiles><smiles>O=CCC[18OH]</smiles><smiles>CCC(=O)CC(C)[O-]</smiles><smiles>C=C</smiles><smiles></smiles>

Alkoxy radicals from the main ketohydroperoxide from 2-methyl-pentane<smiles>CC(=O)CC(C)(C)[O]</smiles><smiles>CCC([O])C(C)C=O</smiles>

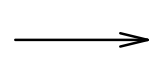

$\longrightarrow$<smiles>CC(=O)I</smiles><smiles>CC(C)=O</smiles>

acetone<smiles>CCC=O</smiles><smiles>CCC=O</smiles>

propanal

Alkoxy radicals from the main ketohydroperoxide from 3-methyl-pentane<smiles>CC(=O)C(C)C(C)[O-]</smiles><smiles>CCCC(C)=O</smiles><smiles>[CH2+][C+]C=O</smiles>

Figure 22. Easiest decomposition routes of alkoxy radicals obtained from the decomposition of the most probable ketohydroperoxides formed during the oxidation of $n$-hexane, 2-methyl-pentane, and 3-methylpentane.

Alkoxy radicals obtained from ketohydroperoxides can also be a source of diones by breaking a C-H bond or reacting with $\mathrm{O}_{2}$ and via an isomerization to form a hydroxyl radical which then reacts with $\mathrm{O}_{2}(32)$. The signal of diones from 2,2-dimethyl-butane is notably lower than those from the three other isomers, which supports the fact that diones are derived from ketohydroperoxides (Figure 20a). Note that the signal at $\mathrm{m} / \mathrm{z} 114$ obtained for the four most reactive fuels (Figure 20a) was about half of that obtained for cyclic ethers (Figure 19a). This would suggest that these species are formed in significant amounts if we consider that both types of species have similar cross sections. A more accurate quantification of SVUV-PIMS data would require knowing the photoionization cross sections of these species. However, they are not easily available at present.

As shown in Figure 20, the GC mole fraction profile of 2,4-hexadione (Figure 20d) is slightly different from the corresponding SVUV-PIMS signal profile (Figure 20a), with a maximum mole fraction of about $5 \times 10^{-3}$, which is much larger than the sum of maximum mole fractions of cyclic ethers. This improbable phenomenon 
suggests a possible decomposition of ketohydroperoxides in the heated transfer line between the outlet of the reactor and the gas chromatograph, as already observed in a previous study on the oxidation of $n$-heptane (32).

Note that a signal about 8 times lower than that of $m / z 114$ is also observed for $m / z 116$ for the four more reactive isomers. This signal at $m / z=M+2$ compared to diones (M) has already be observed in the case of $n$-butane (57) and was attributed to species including a carbonyl and hydroxyl function. It can be formed from alkoxy radicals obtained from ketohydroperoxides by $\mathrm{H}$ atom abstraction from the reactant or by reaction with $\mathrm{HO}_{2}$ radicals. This type of species was not obtained from $n$-heptane oxidation probably due to the too low inlet mole fraction used (0.005 instead of 0.02 here) (32).

A last important product which could be obtained from ketohydroperoxides is acetic acid (see Figure 10). It was detected by SVUV-PIMS for $n$-hexane, the two methyl-pentane isomers, but not for 2,2-dimethyl-butane. While a production pathway from acetaldehyde can be envisaged (32), a direct way of formation from ketohydroperoxides has recently been proposed by Jalan et al. (58). The comparison between the ranking of the formation of acetaldehyde (see Figure 10), ketohydroperoxides (see Figure 20), and acetic acid (see Figure 10) would rather support this last hypothesis, since the three isomers have similar formation of acid and ketohydroperoxides, but some differences can be seen for acetaldehyde (a lower formation for 2-methylpentane).

\section{Conclusion}

The experimental study of the low-temperature oxidation of hexane isomers was performed in a jet-stirred reactor with analysis by gas chromatography and synchrotron vacuum ultraviolet photoionization mass spectrometry (SVUV-PIMS). A satisfactory agreement was obtained for species that could be quantified using both analytical methods. SVUV-PIMS analyses were useful for the quantification of species like water, formaldehyde, organic acids, diones, and ketohydroperoxides, which cannot be quantified by gas chromatography.

Hexane isomers exhibit different reactivities, which are consistent with octane numbers: $n$-hexane is the most reactive, 2-and 3-methyl-pentanes have about the same reactivities which is less than that of $n$-hexane, 2,2-dimethyl-butane was less reactive than methyl-pentane isomers, while 2,3-dimethyl-butane was not reactive under the conditions of this study (fuel inlet mole fraction of 0.02 ).

Many reaction products were identified and quantified during the study. Great attention was paid to the typical low-temperature oxidation products such as alkenes, cyclic ethers, ketones, aldehydes, diones, and ketohydroperoxides with the same skeleton as the reactant. As far as cyclic ethers are concerned, almost all expected isomers were detected (3-, 4-, 5-, and 6-membered ring cyclic ethers), whereas the observation of these species is limited to ones with a 5-membered ring in studies available in the literature. The observation of diones, ketohydroperoxides, and organic acids extends the results obtained in previous studies for linear alkanes to the case of branched reactants. A link, based on the products that are formed through the decomposition of ketohydroperoxides, was found between the type of major $C_{2}-C_{3}$ aldehydes and ketones and the structure of the less-branched fuels. Evidence confirming the formations of diones and acids from ketohydroperoxides have been found. 
This set of experimental data will help in developing and validating detailed kinetic models for the oxidation of branched alkanes that better reproduce the formation of oxidation products such as cyclic ethers.

\section{Supplementary material}

Supplementary material includes a word file with the comparison of data obtained using gas chromatography and SVUV-PIMS, the mass spectra of cyclic ethers which were not in databases, and the structures of the parent cations obtained from the ionization of ketohydroperoxydes and diones.

\section{Acknowledgment}

This study was supported by the European Commission through the "Clean ICE" Advanced Research Grant of the European Research Council and COST Action CM0901.

\section{References}

(1) Pitz, W. J.; Mueller, C. J. Prog. Energy Combust. Sci. 2011, 37, 330-350.

(2) Ward, C. C.; Schwartz, F. G.; Adams, N. G. Ind. Eng. Chem. 1951, 43, 1117-1119.

(3) Ogura, T.; Nagumo, Y.; Miyoshi, A.; Koshi, M. Energy Fuels 2007, 21, 130-135.

(4) Healy, D.; Donato, N. S.; Aul, C. J.; Petersen, E. L.; Zinner, C. M.; Bourque, G.; Curran, H. J. Combust. Flame 2010, 157, 1526-1539.

(5) Healy, D.; Donato, N. S.; Aul, C. J.; Petersen, E. L.; Zinner, C. M.; Bourque, G.; Curran, H. J. Combust. Flame 2010, 157, 1540-1551.

(6) Gersen, S.; Mokhov, A. V.; Darmeveil, J. H.; Levinsky, H. B. Combust. Flame 2010, 157, 240-245.

(7) Minetti, R.; Ribaucour, M.; Carlier, M.; Sochet, L. R. Combust. Sci. Technol. 1996, 113, 179-192.

(8) Silke, E. J.; Curran, H. J.; Simmie, J. M. Proc. Combust. Inst. 2005, 30, 2639-2647.

(9) Davidson, D. F.; Herbon, J. T.; Horning, D. C.; Hanson, R. K. Int. J. Chem. Kinet. 2001, 33, 775-783.

(10) Olchanski, E.; Burcat, A. Int. J. Chem. Kinet. 2006, 38, 703-713.

(11) Zhukov, V. P.; Sechenov, V. A.; Starikovskii, A. Y. Combust. Flame 2008, 153, 130-136.

(12) Zeppieri, S. P.; Klotz, S. D.; Dryer, F. L. Proc. Combust. Inst. 2000, 28, 1587-1595.

(13) Dagaut, P. Phys. Chem. Chem. Phys. 2002, 4, 2079-2094.

(14) Pfahl, U.; Fieweger, K.; Adomeit, G. Proc. Combust. Inst. 1996, 26, 781-789.

(15) Agosta, A.; Cernansky, N. P.; Miller, D. L.; Faravelli, T.; Ranzi, E. Exp. Therm. Fluid Sci. 2004, 28, 701708.

(16) Ristori, A.; Dagaut, P.; Cathonnet, M. Combust. Flame 2001, 125, 1128-1137.

(17) Westbrook, C. K.; Pitz, W. J.; Curran, H. J.; Boercker, J.; Kunrath, E. Int. J. Chem. Kinet. 2001, 33, 868-877.

(18) Kahandawala, M. S. P.; DeWitt, M. J.; Corporan, E.; Sidhu, S. S. Energy Fuels 2008, 22, 3673-3679.

(19) Sarathy, S. M.; Westbrook, C. K.; Mehl, M.; Pitz, W. J.; Togbe, C.; Dagaut, P.; Wang, H.; Oehlschlaeger, M. A.; Niemann, U.; Seshadri, K.; Veloo, P. S.; Ji, C.; Egolfopoulos, F. N.; Lu, T. Combust. Flame 2011, 158, 2338-2357.

(20) Karsenty, F.; Sarathy, S. M.; Togbé, C.; Westbrook, C. K.; Dayma, G.; Dagaut, P.; Mehl, M.; Pitz, W. J. Energy Fuels 2012, 26, 4680-4689.

(21) Sarathy, S. M.; Javed, T.; Karsenty, F.; Heufer, A.; Wang, W.; Park, S.; Elwardany, A.; Farooq, A.; Westbrook, C. K.; Pitz, W. J.; Oehlschlaeger, M. A.; Dayma, G.; Curran, H. J.; Dagaut, P. Combust. Flame 2014, 161, 1444-1459. 
(22) Walker, R. W.; Morley, C. Chapter 1 Basic chemistry of combustion; 1997; Vol. 35.

(23) Zádor, J.; Taatjes, C. A.; Fernandes, R. X. Prog. Energy Combust. Sci. 2011, 37, 371-421.

(24) Eskola, A. J.; Welz, O.; Savee, J. D.; Osborn, D. L.; Taatjes, C. A. J. Phys. Chem. A 2013, 117, $12216-$ 12235.

(25) Eskola, A. J.; Welz, O.; Savee, J. D.; Osborn, D. L.; Taatjes, C. A. Proc. Combust. Inst. 2013, 34, 385392.

(26) Guibet, J.-C. Carburants et moteurs: technologies, énergie, environnement; Editions OPHRYS, 1997.

(27) Battin-Leclerc, F.; Rodriguez, A.; Husson, B.; Herbinet, O.; Glaude, P.-A.; Wang, Z.; Cheng, Z.; Qi, F. J. Phys. Chem. A 2014, 118, 673-683.

(28) Herbinet, O.; Dayma, G. In Cleaner Combustion; Battin-Leclerc, F.; Simmie, J. M.; Blurock, E., Eds.; Green Energy and Technology; Springer London, 2013; pp. 183-210.

(29) Glaude, P. A.; Herbinet, O.; Bax, S.; Biet, J.; Warth, V.; Battin-Leclerc, F. Combust. Flame 2010, 157, 2035-2050.

(30) Bax, S.; Hakka, M. H.; Glaude, P.-A.; Herbinet, O.; Battin-Leclerc, F. Combust. Flame 2010, 157, 1220-1229.

(31) Battin-Leclerc, F.; Herbinet, O.; Glaude, P.-A.; Fournet, R.; Zhou, Z.; Deng, L.; Guo, H.; Xie, M.; Qi, F. Angew. Chem. - Int. Ed. 2010, 49, 3169-3172.

(32) Herbinet, O.; Husson, B.; Serinyel, Z.; Cord, M.; Warth, V.; Fournet, R.; Glaude, P.-A.; Sirjean, B.; Battin-Leclerc, F.; Wang, Z.; Xie, M.; Cheng, Z.; Qi, F. Combust. Flame 2012, 159, 3455-3471.

(33) Tranchant, J. MANUEL PRATIQUE DE CHROMATOGRAPHIE EN PHASE GAZEUSE. 4ème édition; Édition : 4e.; Masson: Paris, 1995.

(34) Herbinet, O.; Battin-Leclerc, F.; Bax, S.; Gall, H. L.; Glaude, P.-A.; Fournet, R.; Zhou, Z.; Deng, L.; Guo, H.; Xie, M.; Qi, F. Phys. Chem. Chem. Phys. 2011, 13, 296-308.

(35) Li, Y.; Qi, F. Acc. Chem. Res. 2010, 43, 68-78.

(36) Samson, J. a. R.; Stolte, W. C. J. Electron Spectrosc. Relat. Phenom. 2002, 123, 265-276.

(37) El-Sherbini, T. M.; Van der Wiel, M. J. Physica 1972, 59, 433-452.

(38) Shaw, D.; Holland, D.; Hayes, M.; Macdonald, M.; Hopkirk, A.; Mcsweeney, S. Chem. Phys. 1995, 198, 381-396.

(39) Dehmer, P.; Holland, D. J. Chem. Phys. 1991, 94, 3302-3314.

(40) Kameta, K.; Kouchi, N.; Ukai, M.; Hatano, Y. J. Electron Spectrosc. Relat. Phenom. 2002, 123, 225238.

(41) Zhou, Z.; Zhang, L.; Xie, M.; Wang, Z.; Chen, D.; Qi, F. Rapid Commun. Mass Spectrom. 2010, 24, 1335-1342.

(42) Cooper, G.; Anderson, J. E.; Brion, C. E. Chem. Phys. 1996, 209, 61-77.

(43) Cool, T. A.; Wang, J.; Nakajima, K.; Taatjes, C. A.; Mcllroy, A. Int. J. Mass Spectrom. 2005, 247, $18-$ 27.

(44) Adam, T.; Zimmermann, R. Anal. Bioanal. Chem. 2007, 389, 1941-1951.

(45) Cool, T. A.; Nakajima, K.; Mostefaoui, T. A.; Qi, F.; Mcllroy, A.; Westmoreland, P. R.; Law, M. E.; Poisson, L.; Peterka, D. S.; Ahmed, M. J. Chem. Phys. 2003, 119, 8356-8365.

(46) Wang, J.; Yang, B.; Cool, T. A.; Hansen, N.; Kasper, T. Int. J. Mass Spectrom. 2008, 269, 210-220.

(47) Yang, B.; Wang, J.; Cool, T. A.; Hansen, N.; Skeen, S.; Osborn, D. L. Int. J. Mass Spectrom. 2012, 309, 118-128.

(48) Dagaut, P.; Reuillon, M.; Cathonnet, M. Combust. Flame 1995, 101, 132-140.

(49) Herbinet, O.; Bax, S.; Glaude, P.-A.; Carré, V.; Battin-Leclerc, F. Fuel 2011, 90, 528-535.

(50) Wijaya, C. D.; Sumathi, R.; Green, W. H. J. Phys. Chem. A 2003, 107, 4908-4920.

(51) Dagaut, P.; Reuillon, M.; Cathonnet, M. Combust. Sci. Technol. 1994, 95, 233-260. 
(52) Dagaut, P.; Reuillon, M.; Cathonnet, M. Combust. Sci. Technol. 1994, 103, 315-336.

(53) Dagaut, P.; Reuillon, M.; Cathonnet, M. Combust. Sci. Technol. 1994, 103, 349-359.

(54) Battin-Leclerc, F. Prog. Energy Combust. Sci. 2008, 34, 440-498.

(55) Montgomery Jr., J. A.; Frisch, M. J.; Ochterski, J. W.; Petersson, G. A. J. Chem. Phys. 1999, 110, 2822-2827.

(56) Frisch, M. J.; Trucks, G. W.; Schlegel, H. B.; Scuseria, G. E.; Robb, M. A.; Cheeseman, J. R.; Montgomery, J. A.; Vreven, T.; Kudin, K. N.; Burant, J. C.; Millam, J. M.; Iyengar, S. S.; Tomasi, J.; Barone, V.; Mennucci, B.; Cossi, M.; Scalmani, G.; Rega, N.; Petersson, G. A.; Nakatsuji, H.; Hada, M.; Ehara, M.; Toyota, K.; Fukuda, R.; Hasegawa, J.; Ishida, M.; Nakajima, T.; Honda, Y.; Kitao, O.; Nakai, H.; Klene, M.; Li, X.; Knox, J. E.; Hratchian, H. P.; Cross, J. B.; Bakken, V.; Adamo, C.; Jaramillo, J.; Gomperts, R.; Stratmann, R. E.; Yazyev, O.; Austin, A. J.; Cammi, R.; Pomelli, C.; Ochterski, J. W.; Ayala, P. Y.; Morokuma, K.; Voth, G. A.; Salvador, P.; Dannenberg, J. J.; Zakrzewski, V. G.; Dapprich, S.; Daniels, A. D.; Strain, M. C.; Farkas, O.; Malick, D. K.; Rabuck, A. D.; Raghavachari, K.; Foresman, J. B.; Ortiz, J. V.; Cui, Q.; Baboul, A. G.; Clifford, S.; Cioslowski, J.; Stefanov, B. B.; Liu, G.; Liashenko, A.; Piskorz, P.; Komaromi, I.; Martin, R. L.; Fox, D. J.; Keith, T.; Laham, A.; Peng, C. Y.; Nanayakkara, A.; Challacombe, M.; Gill, P. M. W.; Johnson, B.; Chen, W.; Wong, M. W.; Gonzalez, C.; Pople, J. A. Gaussian 03, Revision B.03ID - 157, 2004.

(57) Battin-Leclerc, F.; Herbinet, O.; Glaude, P.-A.; Fournet, R.; Zhou, Z.; Deng, L.; Guo, H.; Xie, M.; Qi, F. Proc. Combust. Inst. 2011, 33, 325-331.

(58) Jalan, A.; Alecu, I. M.; Meana-Pañeda, R.; Aguilera-Iparraguirre, J.; Yang, K. R.; Merchant, S. S.; Truhlar, D. G.; Green, W. H. J. Am. Chem. Soc. 2013, 135, 11100-11114. 